\title{
Rhodium(I) Complexes with Hemilabile Phosphines: Rational Design for Efficient Oxidative Amination Catalysts.
}

\author{
M. Victoria Jiménez, ${ }^{*}$ M. Isabel Bartolomé, Jesús J. Pérez-Torrente, ${ }^{\star}$ Fernando J. \\ Lahoz, and Luis A. Oro ${ }^{[a]}$
}

A series of cationic square planar rhodium(I) complexes of type $\left[\mathrm{Rh}(\mathrm{cod})\left\{\mathrm{Ar}_{2} \mathrm{P}\left(\mathrm{CH}_{2}\right)_{n} \mathrm{Z}\right\}\right]^{+}, \quad\left[\mathrm{Rh}(\mathrm{cod})\left\{\mathrm{Ar}_{2} \mathrm{P}\left(\mathrm{CH}_{2}\right)_{\mathrm{n}} \mathrm{Z}\right\}_{2}\right]^{+} \quad$ and $\left.\left[R \mathrm{Rr}_{2} \mathrm{P}\left(\mathrm{CH}_{2}\right)_{n} \mathrm{Z}\right\}_{2}\right]^{+}$containing diverse functionalized phosphine ligands of hemilabile character, $\operatorname{Ar}_{2} P\left(\mathrm{CH}_{2}\right)_{n} \mathrm{Z}(\mathrm{n}=1,2$, or $3 ; \mathrm{Z}=\mathrm{OMe}$, $\mathrm{OEt}, \mathrm{OnBu}, \mathrm{NMe}_{2}, \mathrm{SMe}$ ), have been synthesized and fully characterized by spectroscopic means. The crystal structure of representative compounds has been determined by X-ray diffraction methods. Most complexes are active catalysts for the antiMarkovnikov oxidative amination of styrene with piperidine to produce
(E)-1-styrylpiperidine. Catalyst screening has shown a remarkable relationship between the hemilabile ligand, the pre-catalyst structure and catalytic activity. The more efficient catalysts are those having arylphosphine ligands with a 2-alkoxoethyl or 3-alkoxopropyl hemilabile moiety, $\operatorname{Ar}_{2} \mathrm{P}\left(\mathrm{CH}_{2}\right)_{n} \mathrm{OR}(\mathrm{n}=2,3 ; \mathrm{R}=\mathrm{Me}$, Et, $n \mathrm{Bu})$. This study has shown the outstanding catalytic activity of the bisphosphine complexes $\left[\mathrm{Rh}\left\{\left(4-\mathrm{R}-\mathrm{C}_{6} \mathrm{H}_{4}\right)_{2} \mathrm{P}\left(\mathrm{CH}_{2}\right)_{3} \mathrm{OEt}\right\}_{2}\right]\left[\mathrm{PF} \mathrm{F}_{6}\right](\mathrm{R}=\mathrm{H}, \mathrm{Me}$, $\mathrm{OMe})$ with unprecedented turnover frequencies up to $80 \mathrm{~h}^{-1}(\mathrm{R}=\mathrm{Me})$ and excellent enamine selectivity (96\%).

\section{Introduction}

The catalytic intermolecular hydroamination ${ }^{[1]}$ of unsaturated substrates is an alternative to the classic organic synthesis of nitrogen containing compounds ${ }^{[2]}$ that is affected by thermodynamic and kinetic barriers. ${ }^{[3]}$ The catalysis methodology presents several advantages: one step reactions, $100 \%$ atom efficiency and, at the same time, use available and low cost feedstocks.

In spite of the recent advances in the field of intramolecular alkene hydroamination, ${ }^{[4]}$ the intermolecular hydroamination, and in particular, the anti-Markovnikov functionalization of unactivated olefins with amines, still remains an important challenge in catalysis. Reaction products can be amines, as a consequence of a formal $\mathrm{N}-\mathrm{H}$ bond addition to the unsaturated carbon-carbon bond, or enamines, as a result of an oxidative amination (Scheme 1). ${ }^{[5]}$ The control of the regioselectivity is an important issue as both anti-Markovnikov products are of industrial significance.

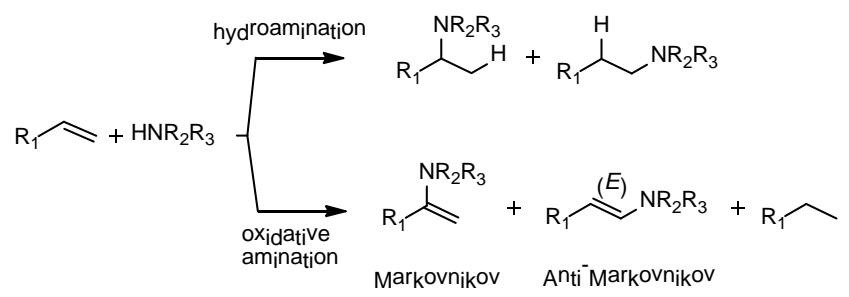

Scheme 1. Hydroamination/oxidative amination of olefins with secondary amines

The first reported late transition metal catalysts for intermolecular hydroamination were rhodium salts used by DuPont in the hydroamination of ethylene with secondary amines. ${ }^{[6]}$ Later on, Taube studied the reaction mechanism with complex $\left.\left[\mathrm{RhCl}\left(\mathrm{C}_{2} \mathrm{H}_{4}\right) \text { (piperidine }\right)_{2}\right]$ that exhibited a superior catalytic activity. ${ }^{[7,8]}$ Subsequently, Milstein ${ }^{[9]}$ described the iridium catalytic system $\left[\mathrm{IrCl}\left(\mathrm{PEt}_{3}\right)_{2}\left(\mathrm{C}_{2} \mathrm{H}_{4}\right)_{2}\right] / \mathrm{ZnCl}_{2}$, and confirmed that the hydroamination of styrene with aniline takes place through a N-H activation mechanism. Interestingly, although the analogue rhodium compound showed very low activity, the system $\left[\left\{\mathrm{RhCl}\left(\mathrm{PEt}_{3}\right)_{2}\right\}_{2}\right] / \mathrm{Li}\left(\mathrm{NHC}_{6} \mathrm{H}_{5}\right)$, reported by Brunet, presents a moderate catalytic activity giving simultaneously the hydroamination and the oxidative amination products, both with Markovnikov selectivity. ${ }^{[10]}$

Further examples of efficient late transition metal intermolecular hydroamination catalysts involve group 8 and 10 transition metals as palladium, $\left[\mathrm{Pd}\left(\mathrm{PPh}_{3}\right)_{4}\right]$ or $\left[\mathrm{Pd}\left(\mathrm{OC}(\mathrm{O}) \mathrm{CF}_{3}\right)_{2}\right] / d p p f$ with $\mathrm{CF}_{3} \mathrm{SO}_{3} \mathrm{H}$, which catalyze the Markovnikov addition of anilines to vinylarenes, ${ }^{[11]}$ or platinum, $\left[\mathrm{Pt}(\mathrm{OTf})_{2} \mathrm{~L}_{2}\right]\left(\mathrm{L}_{2}=\mathrm{SBINAP}, t\right.$ Bubpy, dppe, etc. $)$, that catalyze the addition of arylsulfonamides and weakly basic anilines to alkenes. $^{[12]}$ The same selectivity was observed in alternative reaction media as ionic liquids with the system $\left[\mathrm{PtBr}_{2}\right] / \mathrm{H}^{+}$. ${ }^{[3]} \mathrm{On}$ the other hand, the catalytic systems based on mononuclear NHC-

[a] M. V. Jiménez, M. I. Bartolomé, J. J. Pérez-Torrente, F. J. Lahoz, L. A. Oro

Departamento de Química Inorgánica, Instituto de Síntesis Química y Catálisis Homogénea (ISQCH), Universidad de Zaragoza-C.S.I.C.

Pedro Cerbuna 12, 50009-Zaragoza, Spain. E-mail: vjimenez@unizar.es, perez@unizar.es

Supporting information for this article is available on the WWW under http://dx.doi.org/10.1002/cctc.200xxxxxx 
carbene or diphosphine copper(I) complexes, ${ }^{[14]}$ and $[\mathrm{Ru}(\mathrm{cod})(2-$ methylallyl) $)_{2}$ /DPPPent/HOTf (DPPPent $=1,5-$ bis (diphenylphosphino)pentane ${ }^{[15]}$ are isolated examples of intermolecular hydroamination with anti-Markovnikov regioslectivity.

At the end of the 1990s, Beller et al. described the first catalytic system for the regioselective anti-Markonikov oxidative amination of styrene with secondary amines. ${ }^{[16]}$ The rhodium catalytic system, $\left[\mathrm{Rh}(\mathrm{cod})_{2}\right] \mathrm{BF}_{4} / 2 \mathrm{PPh}_{3}$, allows to obtain selectively the linear enamine together with ethylbenzene in equimolecular quantities. ${ }^{[17]}$ The system also proved to be active in the hydroamination of vinylpyridines ${ }^{[18]}$ producing mixtures of the hydroamination and oxidative amination products. More recently, Hartwig, using the catalyst $[\mathrm{Rh}(\mathrm{cod})(\mathrm{DPEphos})]\left[\mathrm{BF}_{4}\right]$ (DPEphos = bis-(2-diphenylphosphinophenyl)ether), $\left.{ }^{[19}\right]$ has observed the regioselective anti-Markonikov hydroamination of vinylarenes with moderate selectivity due to the formation of enamine. In this case, the flexibility of the ether-diphosphine ligand is a keystone since other less flexible ether-diphosphine ligands, as Xantphos or DBFphos, and diphosphines such as DPPE, DPPB or DPPPent, resulted in unactive systems. However, the catalyst efficiency in both systems was generally low as a maximum TOFs of 1.5 and 0.26 turnovers per hour were attained with the Beller ${ }^{[16]}$ and Hartwig ${ }^{[19]}$ catalytic systems, respectively.

Hemilabile ligands having electronically divergent donor atoms have been intensively investigated in catalysis stimulated by their potential for the generation of accessible coordination vacancies or protecting the active catalytic site, through a dynamic "on and off" chelating effect for the metal center. In addition, the hemilabile ligands can also play a role in the stabilization of highly unsaturated intermediates, the interaction with reactive polar species or even the activation of substrates. In this context, hemilabile ligands can influence the catalytic activity due to their bi-functional character as it has been observed for several catalytic transformations as alkyne hydration or transfer hydrogenation. ${ }^{[20]}$ We have recently reported rhodium and iridium compounds containing functionalized $\mathrm{NHC}$ carbene ligands of hemilabile character as efficient hydrosilylation ${ }^{[21]}$ and hydrogen transfer ${ }^{[22]}$ catalysts, respectively. Interestingly, in the later case, we have indentified an active role of the -OMe hemilabile tail of the $\mathrm{NHC}$ ligands for promoting the $\beta-\mathrm{H}$ elimination step from alcoxo intermediates in route to the key hydrido intermediate species.

Alkylamino functionalized phosphines of hemilabile character have proven to be very effective for the design of rhodium catalysts for the stereoregular phenylacetylene polymerization. ${ }^{[23]}$ In the light of the active role of the hemilabile fragment in the generation of the alkynyl catalytic active species, we have also explored their potential for the design of efficient hydroamination catalysts. Inspired by the Beller catalytic system, $\left[\mathrm{Rh}(\mathrm{cod})_{2}\right] \mathrm{BF}_{4} / 2 \mathrm{PPh}_{3}$, we have followed the approach of using flexible hemilabile functionalized phosphines to modify this system. However, in order to get detailed information on the phosphine influence in the catalytic activity, we have used well-characterized rhodium complexes as catalyst precursors, as an alternative to the in situ generation of them.

We report herein the results of a screening study for a library of hemilabile functionalized phosphines that show an interesting relationship between pre-catalyst structure and catalytic activity. This study has lead to the design of efficient rhodium catalysts based on flexible functionalized P,O-phosphine ligands for the regioselective anti-Markovnikov oxidative amination of styrene with piperidine. A preliminary account of this work has been recently communicated. ${ }^{[24]}$

\section{Results and Discussion}

\section{Catalyst screening: Performance of different P-donor ligands} in the catalytic oxidative amination of styrene.

The catalytic hydroamination of styrene with piperidine has been selected as benchmark reaction for the exploration of the catalytic activity of the different complexes. The reactions were conducted using an excess of styrene under the optimized conditions set up by Beller ${ }^{[16]}$ et al for the catalytic system $\left[\mathrm{Rh}(\operatorname{cod})_{2}\right]\left[\mathrm{BF}_{4}\right] / 2 \mathrm{PPh}_{3}$. The oxidative amination and hydroamination anti-Markovnikov products, $(E)$-1-styrylpiperidine (a) and 1-phenylethylpiperidine (b), respectively, were obtained as main products together with a roughly equimolar amount of ethylbenzene (c) (Table 1) arising from the hydrogenation of styrene, which is in agreement with its hydrogen acceptor role in the generally accepted mechanism for the oxidative amination. ${ }^{[3,4,17]}$

In order to explore the performance of diverse hemilabile $\mathrm{P}$ donor ligands, $P \cap Z$, a preliminary screening of the catalytic systems $\left[R h(\operatorname{cod})_{2}\right]^{+} /(P \cap Z)$ using different ligans, most of them 2methoxyethyl functionalized P-donor ligands, has been carried out (Table 1).

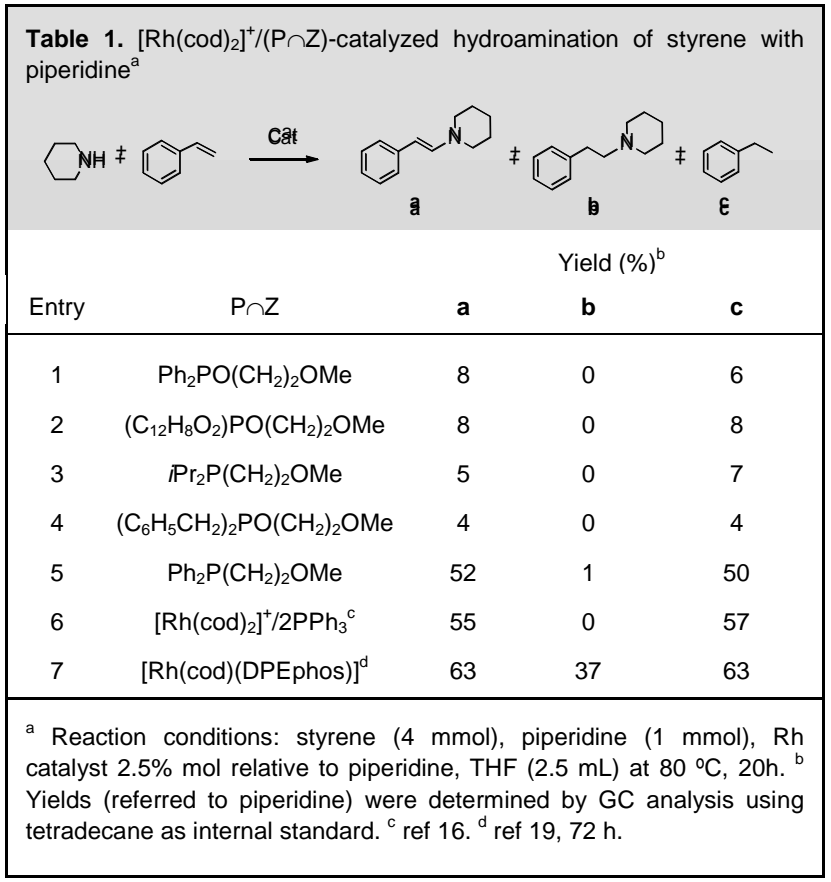

The catalytic systems based on diamido-phosphite esters, $\left(i \mathrm{Pr}_{2} \mathrm{~N}\right)_{2} \mathrm{PO}\left(\mathrm{CH}_{2}\right)_{2} \mathrm{OMe}$; ketophosphines, $\mathrm{Ph}_{2} \mathrm{PCH}_{2} \mathrm{C}(\mathrm{O}) \mathrm{Ph}$; or allylphosphines, $\mathrm{Ph}_{2} \mathrm{PCH}_{2} \mathrm{CH}=\mathrm{CH}_{2},\left(4-\mathrm{FC}_{6} \mathrm{H}_{4}\right)_{2} \mathrm{PCH}_{2} \mathrm{CH}=\mathrm{CH}_{2}$ and $\left(\mathrm{C}_{6} \mathrm{~F}_{5}\right)_{2} \mathrm{PCH}_{2} \mathrm{CH}=\mathrm{CH}_{2}$, were found to be inactive. On the other hand, phosphinite and phosphite ligands, $\mathrm{Ph}_{2} \mathrm{PO}\left(\mathrm{CH}_{2}\right)_{2} \mathrm{OMe}$ and $\left(\mathrm{C}_{12} \mathrm{H}_{8} \mathrm{O}_{2}\right) \mathrm{PO}\left(\mathrm{CH}_{2}\right)_{2} \mathrm{OMe}$, gave less than $10 \%$ conversion after $20 \mathrm{~h}$ (entries 1 and 2). The most efficient catalytic system was the one based on the diaryl-phosphine ligand $\mathrm{Ph}_{2} \mathrm{P}\left(\mathrm{CH}_{2}\right)_{2} \mathrm{OMe}$ (entry 5). Dialkyl phosphines as, $\operatorname{PPr}_{2} \mathrm{P}\left(\mathrm{CH}_{2}\right)_{2} \mathrm{OMe}$ and $\left(\mathrm{C}_{6} \mathrm{H}_{5} \mathrm{CH}_{2}\right)_{2} \mathrm{P}\left(\mathrm{CH}_{2}\right)_{2} \mathrm{OMe}$, were much less efficient (entries 3 and 4). Thus, taking as a reference the catalytic activity of the system $\left[\mathrm{Rh}(\mathrm{cod})_{2}\right]^{+} / \mathrm{Ph}_{2} \mathrm{P}\left(\mathrm{CH}_{2}\right)_{2} \mathrm{OMe}$, comparable to the exhibited by the systems $\left[\mathrm{Rh}(\mathrm{cod})_{2}\right]^{+} / 2 \mathrm{PPh}_{3}{ }^{[16]}$ and $[\mathrm{Rh}(\mathrm{cod})(\mathrm{DPEphos})]^{{ }^{[19]} \text {, with }}$ good chemioselectivity to the oxidative amination product and antiMarkovnikov regioselectivity, an exhaustive study on the synthesis of different catalysts precursor containing flexible functionalized diarylphosphines $(P \cap Z)$ has been carried out in order to determine 
the influence of the hemilabile ligand and catalyst structure on the catalytic activity.

The functionalized phosphine ligands used in this study, $\mathrm{Ar}_{2} \mathrm{P}\left(\mathrm{CH}_{2}\right)_{n} \mathrm{Z},\left(\mathrm{Z}=\mathrm{OR}, \mathrm{NR}_{2}, \mathrm{SR}\right),{ }^{[25]}$ combine strong electron donors and weak donor functions linked by a flexible backbone. These ligands offer potential for the modulation of the electronic density on the phosphorus donor atom by introducing electrondonating or electron-withdrawing substituents in the aryl groups of the phosphine fragment, as well as for the control of the coordination ability of the hemilabile fragment by the selection of the donor group or the length of the flexible carbon chain (Figure 1).

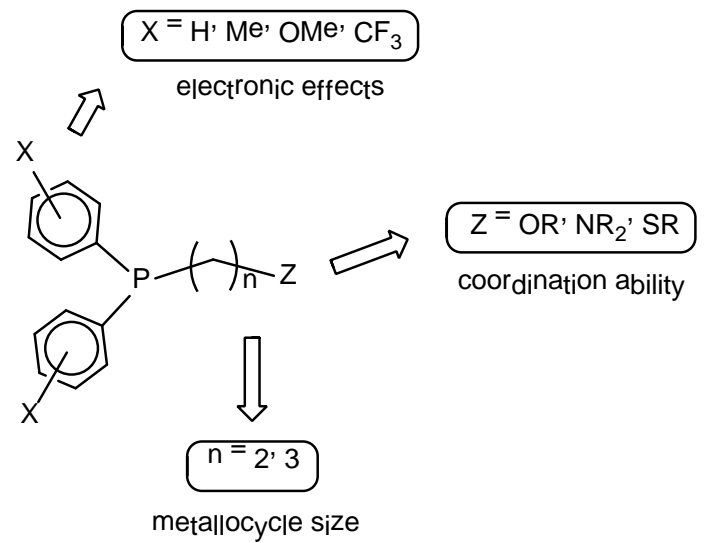

Figure 1. Hemilabile functionalized phosphine ligands for the design of oxidative amination catalysts.

\section{Rhodium catalysts with hemilabile $\operatorname{Ar}_{2} \mathrm{P}\left(\mathrm{CH}_{2}\right)_{n} \mathrm{Z}$ phosphines.}

We have prepared a series of new mononuclear cationic cyclooctadiene-rhodium complexes (Chart 1) having one (Type I) or two (Type II) hemilabile phosphine ligands $\operatorname{Ar}_{2} P\left(\mathrm{CH}_{2}\right)_{n} \mathrm{Z}(\mathrm{n}=2$; 3 ), and the cyclooctadiene free complexes $\left[R h\left\{\mathrm{Ar}_{2} \mathrm{P}\left(\mathrm{CH}_{2}\right)_{3} \mathrm{Z}\right\}_{2}\right]^{+}$ (Type III). The catalyst precursors have been methodically tested in the hydroamination of styrene with piperidine following the optimized conditions. ${ }^{[24]}$

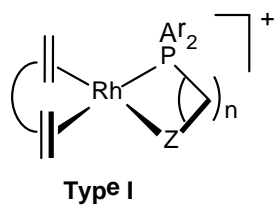

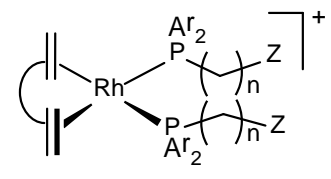

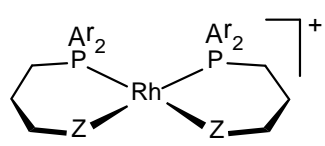

Type III

Chart 1. Different cationic rhodium complexes with hemilabile phosphines $\mathrm{Ar}_{2} \mathrm{P}\left(\mathrm{CH}_{2}\right)_{\mathrm{n}} \mathrm{Z}\left(\mathrm{Z}=\mathrm{OR}, \mathrm{NR}_{2}, \mathrm{SR}, \mathrm{n}=2,3\right)$ studied as catalyst precursors.

Synthesis and characterization of Type I $[R h(c o d)(P \curvearrowright Z)]\left[B F_{4}\right]$ complexes.

The preparation of cationic complexes having a $\mathrm{Ph}_{2} \mathrm{P}\left(\mathrm{CH}_{2}\right)_{\mathrm{n}} \mathrm{Z}$ ligand $\kappa^{2}-P, Z$ coordinated, $[R h(c o d)(P \cap Z)]\left[B_{4}\right](1-13)(C h a r t 2)$, can be accomplished using different synthetic strategies (Scheme 2). The reaction of the hemilabile phosphines with half equiv. of the dimer compound $\left[\{\mathrm{Rh}(\mu-\mathrm{Cl})(\operatorname{cod})\}_{2}\right]$ in acetone or tetrahydrofuran gave the intermediate neutral complexes $[\mathrm{RhCl}(\operatorname{cod})(\mathrm{P} \cap \mathrm{Z})]$ that were reacted with $\mathrm{AgBF}_{4}$ to give the complexes after elimination of the formed $\mathrm{AgCl}$ (method $\mathrm{A}$ ). Alternatively, the compounds can be prepared by addition of one equivalent of the functionalized phosphine to the solvato complex $\left[\mathrm{Rh}(\mathrm{cod})(\text { solvent })_{2}\right]\left[\mathrm{BF}_{4}\right]$ (solvent $=\mathrm{Me}_{2} \mathrm{CO}$ or thf) formed in situ by reaction of $\left[\{\mathrm{Rh}(\mu-\mathrm{Cl})(\mathrm{cod})\}_{2}\right]$ with two equivalents of silver tetrafluoroborate (method $\mathrm{B}$ ). In some cases, the complexes were also obtained starting from $\left[\mathrm{Rh}(\mathrm{cod})_{2}\right]\left[\mathrm{BF}_{4}\right]^{[26]}$ (method C). Finally, some complexes can be also prepared by reaction of the methoxo-bridged complex $\left[\{\mathrm{Rh}(\mu-\mathrm{OMe})(\mathrm{cod})\}_{2}\right]$ with the appropriate phosphonium salt of the functionalized phosphines (method D). In general, method B works well with most of the phosphines although in some cases method A provides slightly better yields. On the other hand, method $D$ was used for phosphines that are either difficult to purify or very sensitive, as for example functionalized alkyl phosphines.

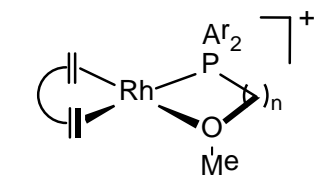

$n=2 \mid \begin{aligned} & A r=P^{\prime} \mathbf{1} \\ & A r=4{ }^{-}{ }^{-} C_{6} H_{4}, 2 \\ & A r=2-\text { Me }_{6} H_{4}, 3\end{aligned}$

\begin{tabular}{l|l}
$n=3$ & $A^{r}=P^{\prime} 4$
\end{tabular}

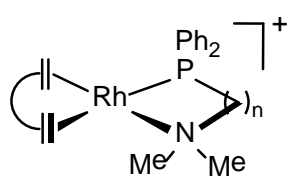

$\mathrm{n}=2,11$

$n=3,12$<smiles>CCOP1[Te]P(I)I1I</smiles>

$\mathrm{n=2} \mid \begin{aligned} & \mathrm{Ar}=\mathrm{Ph} \mathbf{5} \\ & \mathrm{Ar}=4 \mathrm{MeC}_{6} \mathrm{H}_{4}, \mathbf{6} \\ & \mathrm{Ar}^{\mathrm{r}}={ }^{-} \mathrm{CF}_{3} \mathrm{C}_{6} \mathrm{H}_{4}, \mathbf{7}\end{aligned}$

$n=3 \quad \begin{aligned} & \mathrm{Ar}^{\mathrm{r}}=\mathrm{Ph}, \mathbf{8} \\ & \mathrm{Ar}^{\mathrm{r}}=4^{-} \mathrm{Me}_{6} \mathrm{H}_{4}, \mathbf{9} \\ & \mathrm{Ar}^{\mathrm{r}}=4^{-} \mathrm{CF}_{3} \mathrm{C}_{6} \mathrm{H}_{4}, \mathbf{1 0}\end{aligned}$

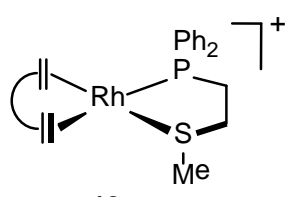

13
Chart 2. Structures of Type I $[\mathrm{Rh}(\mathrm{cod})(\mathrm{P} \cap \mathrm{Z})]\left[\mathrm{BF}_{4}\right](\mathbf{1 - 1 3})$ complexes.

Most of these compounds 1-13 were obtained as yellow or orange crystalline solids by slow diffusion of diethyl ether into concentrated solutions of the complexes in tetrahydrofuran or acetone. Complexes $\mathbf{7}$ and $\mathbf{1 0}$ were isolated as yellow solids. The complexes have been fully characterized by elemental analysis, mass spectra and multinuclear NMR spectroscopy. In particular, full assignment of the resonances in the ${ }^{1} \mathrm{H}$ and ${ }^{13} \mathrm{C}\left\{{ }^{1} \mathrm{H}\right\}$ NMR spectra was done with the help of the correlation ${ }^{1} \mathrm{H},{ }^{1} \mathrm{H}-\mathrm{COSY}$, and ${ }^{1} \mathrm{H},{ }^{13} \mathrm{C}$-HSQC spectra. The ${ }^{1} \mathrm{H}$ NMR spectra of the complexes showed two distinct resonances for the $=\mathrm{CH}$ protons of the cod ligand which is in agreement with a square-planar structure with a functionalized hemilabile phosphine ligand $\kappa^{2}-P, Z(Z=N, O, S)$ coordinated (Cs symmetry). However, both resonances are somewhat broad at room temperature which suggests the existence of conformational equilibria in the metallocycles. ${ }^{[27]}$ Compound $\left[\mathrm{Rh}(\mathrm{cod})\left\{\mathrm{Ph}_{2} \mathrm{P}\left(\mathrm{CH}_{2}\right)_{2} \mathrm{SMe}\right\}\right]^{+}$(13), having the (2(thiomethyl)ethyl)diphenylphosphine ligand, showed featureless signals for the $=\mathrm{CH}$ and $>\mathrm{CH}_{2}$ protons in $\mathrm{CD}_{2} \mathrm{Cl}_{2}$, even at $-80^{\circ} \mathrm{C}$, which could be an indication of an equilibrium involving different species having $\kappa^{2}-\mathrm{P}, \mathrm{S}$ and $\kappa-\mathrm{P}$ coordinated ligands or even polynuclear species. The ${ }^{31} \mathrm{P}\left\{{ }^{1} \mathrm{H}\right\}$ NMR spectra of the complexes 
features a doublet with $J(P, R h)$ coupling constants of ca. $150 \mathrm{~Hz}$, which are in the range of those described for rhodium (I) compounds. ${ }^{[28]}$ This resonance is found in the range $\delta 22-18 \mathrm{ppm}$ for the complexes having six-membered ring metallocycles $(n=3)$ and is shifted to lower fields, $\delta 60-40 \mathrm{ppm}$, in the complexes with five-membered ring metallocycles $(n=2)$.
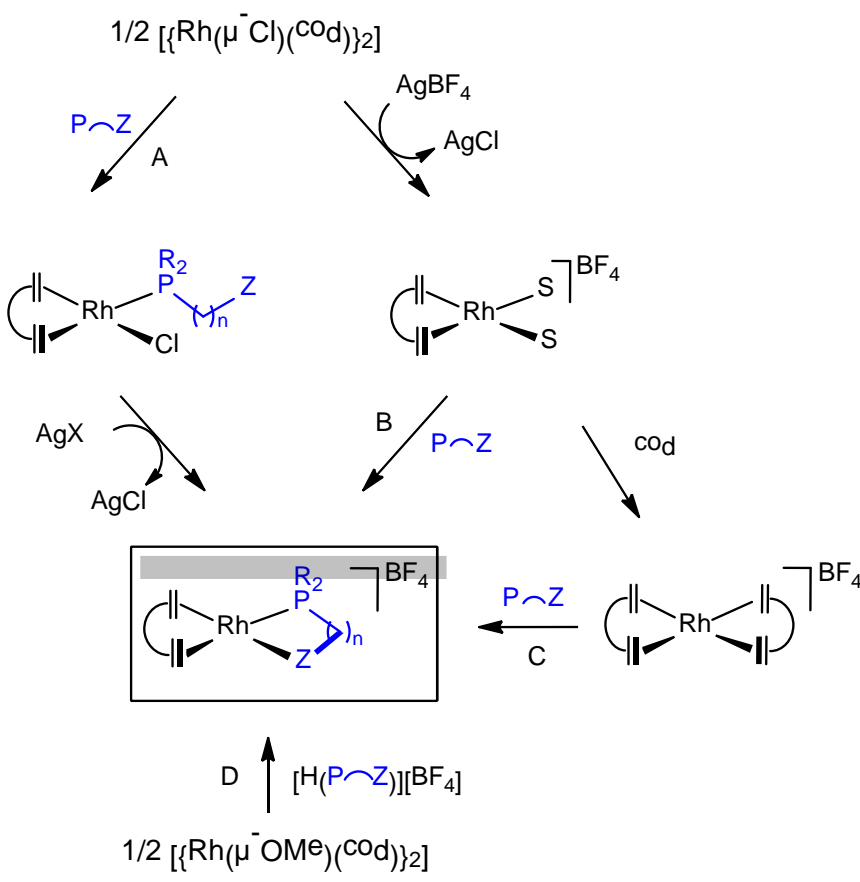

Scheme 2. Synthetic routes for the preparation of Type I $[R h(\operatorname{cod})(P \cap Z)]\left[B F_{4}\right]$ complexes ( $\mathrm{S}=\mathrm{Me}_{2} \mathrm{CO}$ or tetrahydrofuran).

Trying to identify potential differences in the structural parameters of these complexes, the crystal structure of some strategically selected compounds $\left[\mathrm{Rh}(\mathrm{cod})\left\{\mathrm{Ph}_{2} \mathrm{P}\left(\mathrm{CH}_{2}\right)_{2} \mathrm{OMe}\right\}\right]\left[\mathrm{BF}_{4}\right]$ (1), $\quad\left[\mathrm{Rh}(\mathrm{cod})\left\{\left(4-\mathrm{MeC}_{6} \mathrm{H}_{4}\right)_{2} \mathrm{P}\left(\mathrm{CH}_{2}\right)_{2} \mathrm{OMe}\right\}\right]\left[\mathrm{BF}_{4}\right] \quad$ (2), [Rh(cod) $\left.\left\{\mathrm{Ph}_{2} \mathrm{P}\left(\mathrm{CH}_{2}\right)_{3} \mathrm{OEt}\right\}\right]\left[\mathrm{BF}_{4}\right](8)$ and $\left[\mathrm{Rh}(\mathrm{cod})\left\{\left(4-\mathrm{MeC}_{6} \mathrm{H}_{4}\right)_{2} \mathrm{P}\left(\mathrm{CH}_{2}\right)_{3} \mathrm{OEt}\right\}\right]$ $\left[\mathrm{BF}_{4}\right](\mathbf{9})$ were determined by $\mathrm{X}$-ray diffraction. In all cases, the molecular structure of these complexes showed slightly distorted square-planar metal environments (Figure 2); the most representative bond distances and angles are collected in Table 2.

Complexes 1, $\mathbf{2}$ and $\mathbf{8}$ show the metal coordination molecular plane defined by the two olefinic bonds of the cod ligand and the hemilabile phosphine coordinated in a chelate $\kappa^{2}-P, O$ mode. However, complex 9 exhibits the ligand (3-ethoxypropyl)di(paramethylphenyl)phosphine linked to the rhodium atom in a monodentate $\kappa-P$ way, with the fourth coordination position occupied by an oxygen-bonded acetone molecule (used as crystallization solvent). In the light of that result, the proper stoichiometry of the measured single crystal of $\mathbf{9}$ should be stated as $\left[\mathrm{Rh}(\mathrm{cod})\left\{\kappa^{1}-P-\left(4-\mathrm{MeC}_{6} \mathrm{H}_{4}\right)_{2} \mathrm{P}\left(\mathrm{CH}_{2}\right)_{3} \mathrm{OEt}\right\}\left(\mathrm{Me}_{2} \mathrm{CO}\right)\right]\left[\mathrm{BF}_{4}\right] \quad$ (9b). The ${ }^{1} \mathrm{H}$ y ${ }^{13} \mathrm{C}\left\{{ }^{1} \mathrm{H}\right\}$-apt NMR spectra of vacuum-dried crystals of $\mathbf{9 b}$ show the absence of the corresponding resonances for coordinated acetone and the presence of those typical for a chelate coordination of the phosphine ligand, corroborating the $\kappa^{2}$ $P, O$ bonding of the phosphine in solution but, most probably, with a very weak link to the oxygen heteroatom. Additionally, the Rh-P bond distance in $\mathbf{9 b}$ is statistically longer, 2.3083(4) $\AA$, than the analogous distances observed in complexes 1, 2 and $\mathbf{8}$.

All complexes feature metal coordination bond angles slightly different from the ideal square-planar geometry. The most significant deviations are observed in complexes $\mathbf{1}$ and $\mathbf{2}$ for the bite angle of the chelate phosphine, where $\mathrm{P}-\mathrm{Rh}-\mathrm{O}$ angles are $80.29(5)^{\circ}$ and $81.53(8)^{\circ}$, respectively, comparable to those reported for other similar five-membered metallocycles rhodium compounds. On the other hand, the chelate $\mathrm{P}-\mathrm{Rh}-\mathrm{O}$ angle found in $8,89.07(4)^{\circ}$, very close to the ideal value of a square-planar coordination, clearly shows the difference associated to the longer ethoxypropyl moiety, and the existence of a six-membered metallocycle. The higher trans influence of the phosphorus atom, compared to that of oxygen, explains that the bond distances $\mathrm{Rh}-\mathrm{C}(1) / \mathrm{C}(2)$ trans to the phosphorus are significantly longer (over $0.1 \AA$ ) than the $\mathrm{Rh}-\mathrm{C}(5) / \mathrm{C}(6)$ distances trans to the ether group.

\begin{tabular}{|c|c|c|c|c|}
\hline & 1 & 2 & 8 & $9 b$ \\
\hline Rh-P & $2.2914(9)$ & $2.2821(9)$ & $2.2772(6)$ & $2.3084(4)$ \\
\hline Rh-O & $2.174(2)$ & $2.180(3)$ & $2.1795(14)$ & $2.1262(12)$ \\
\hline Rh-C(1) & $2.201(3)$ & $2.218(4)$ & $2.227(2)$ & $2.2011(16)$ \\
\hline Rh-C(2) & $2.240(3)$ & $2.228(4)$ & $2.253(2)$ & $2.2553(17)$ \\
\hline Rh-M(1) & $2.114(2)$ & $2.125(5)$ & $2.1325(15)$ & $2.1196(13)$ \\
\hline Rh-C(5) & $2.094(3)$ & $2.097(3)$ & $2.112(2)$ & $2.1066(17)$ \\
\hline Rh-C(6) & $2.108(3)$ & $2.107(3)$ & $2.116(2)$ & $2.1299(17)$ \\
\hline Rh-M(2) & $1.986(3)$ & $1.985(4)$ & $1.9930(15)$ & $1.9987(12)$ \\
\hline P-Rh-O & $80.29(6)$ & $81.63(8)$ & $89.07(4)$ & $90.62(3)$ \\
\hline P-Rh-M(1) & $171.27(6)$ & $175.37(12)$ & $174.32(4)$ & $173.39(4)$ \\
\hline P-Rh-M(2) & $98.30(8)$ & $97.22(13)$ & $93.24(5)$ & $94.23(4)$ \\
\hline O-Rh-M(1) & $95.70(8)$ & $94.59(14)$ & $91.32(5)$ & $88.15(5)$ \\
\hline O-Rh-M(2) & 169.64(9) & $172.48(13)$ & $176.41(6)$ & $174.96(5)$ \\
\hline$M(1)-R h-M(2)$ & $87.01(10)$ & 86.96(17) & $86.65(6)$ & $87.20(5)$ \\
\hline \multicolumn{5}{|c|}{$\begin{array}{l}{ }^{a} M(1) \text { and } M(2) \text { represent the midpoints of the olefinic bonds } C(1)-C(2) \text { and } \\
C(5)-C(6) \text {, respectively. }\end{array}$} \\
\hline
\end{tabular}

Complexes 1 and 2, showed a slightly distorted envelope ${ }^{3} \mathrm{E}$ conformation for the five-membered metallocycles, with the $C(9)$ atom out of the mean plane defined by $\mathrm{Rh}-\mathrm{P}-\mathrm{C}(9)-\mathrm{C}(10)-\mathrm{O}$ atoms; the calculated puckering parameters being ${ }^{[29]} Q_{T}=$ 0.491(4) $\AA$ and 0.488(5) $\AA$, and $\Phi \square=61.6(3)^{\circ}$ and 75.525$)^{\circ}$ for 1 and 2 , respectively. On the other hand, the six-membered metallocycle, Rh-P-C(9)-C(9B)-C(10)-O, formed in 8 exhibits a ${ }^{1} \mathrm{C}_{4}$ chair conformation with $\mathrm{Rh}$ and $\mathrm{C}(9 \mathrm{~B})$ atoms out of the mean plane of the ring and a slightly higher puckering amplitude, $Q_{\top}=$ $0.6421(16) \AA\left(\Phi \square=72.8(2)^{\mathrm{o}} \text { and } \theta=15.36(15)^{\circ}\right)^{\left[{ }^{[29]}\right.}$

$<<$ Please, find the Figure 2 at the end of the document $>>$ the figure is bigger than one column

Figure 2. Molecular structure of the cations of 1, 2, 8 and $\mathbf{9 b}$. Hydrogen atoms have been omitted for clarity.

Synthesis and characterization of Type II $\left[R h(\operatorname{cod})(P \cap Z)_{2}\right]\left[B F_{4}\right]$ complexes.

Cationic rhodium(I) complexes having two functionalized hemilabile phosphine ligands (Chart 3 ) have been prepared 
following the synthetic methods $\mathrm{B}$ and $\mathrm{C}$ described in Scheme 3. Thus, reaction of $\left[\mathrm{Rh}(\operatorname{cod})(\text { solvent })_{2}\right][\mathrm{X}]$ (solvent $=\mathrm{Me}_{2} \mathrm{CO}$ or thf) or $\left[\mathrm{Rh}(\mathrm{cod})_{2}\right][\mathrm{X}]$ with two equiv. of the hemilabile phosphine gave yellow solution of the compounds $\left[R h(\operatorname{cod})(P \cap Z)_{2}\right][X]\left(X=B_{4}\right.$, $\mathrm{PF}_{6}$ or $\left.\mathrm{SbF}_{6}\right)$ which were isolated as yellow or orange microcrystalline solids in good yield. The ${ }^{31} \mathrm{P}\left\{{ }^{1} \mathrm{H}\right\}$ NMR spectra of these complexes show a doublet in the range $\delta 15-24 \mathrm{ppm}$ indicating equivalent hemilabile phosphine ligands. In addition, the ${ }^{1} \mathrm{H}$ NMR spectra display a single resonance for the $=\mathrm{CH}$ protons of the cod ligand in full agreement with an ideal $\mathrm{C}_{2 v}$ symmetry. The ${ }^{13} \mathrm{C}\left\{{ }^{1} \mathrm{H}\right\}$ NMR spectra are structurally informative on the coordination mode of the hemilabile ligand: $\kappa^{2}-P, X(X=O, N)$ or $\kappa-P$. Thus, the chemical shifts for the carbon atoms of the methyl and methylenic groups attached to the heteroatom $\left(\mathrm{OCH}_{3} / \mathrm{N}\left(\mathrm{CH}_{3}\right)_{2}\right.$, $\mathrm{OCH}_{2} \mathrm{CH}_{3}$ and $\mathrm{OCH}_{2} \mathrm{CH}_{2} \mathrm{CH}_{2} \mathrm{CH}_{3}$ ) in complexes having $\kappa-\mathrm{P}$ coordinated hemilabile ligands were observed shifted at higher fields, ca. $5 \mathrm{ppm}$, compared to those complexes with the phosphine ligand coordinated in a $\kappa^{2}-\mathrm{P}, \mathrm{X}(\mathrm{X}=\mathrm{O}, \mathrm{N})$ fashion (Table 3). In addition, the ortho, meta and ipso aromatic carbons of the phosphine fragment, and the $-\mathrm{CH}_{2}-\mathrm{P}$ resonance in the chain, were observed as virtual triplets by coupling to phosphorous and rhodium with a similar coupling constants.

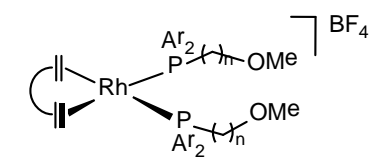

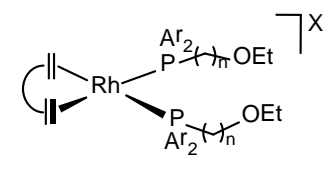

$$
\begin{array}{l|l}
n=2 & A^{r=P h}, 14 \\
n=3 & \begin{array}{l}
A r=P h \cdot 15 \\
A^{r}={ }_{4}^{-} \mathrm{Me}_{6} \mathrm{H}_{4}, 16
\end{array}
\end{array}
$$$$
\mathrm{X}=\mathrm{BF}_{4}
$$$$
\begin{array}{l|l}
\mathrm{n}=2 & \begin{array}{l}
\mathrm{Ar}^{\mathrm{r}}=\mathrm{Ph}^{\prime} 17 \\
\mathrm{Ar}^{\mathrm{r}}={ }^{-} \mathrm{MeC}_{6} \mathrm{H}_{4}, 18
\end{array}
\end{array}
$$$$
\begin{array}{l|l|l}
\mathrm{n}=3 & \mathrm{Ar}=\mathrm{Ph} \cdot 19 \mathrm{a}
\end{array}
$$$$
\mathrm{X}=\mathrm{PF}_{6}, 19 \mathrm{~b}
$$$$
\mathrm{X}=\mathrm{SbF}_{6}, 19 \mathrm{C}
$$$$
\mathrm{Ar}=4^{-} \mathrm{Me}^{-} \mathrm{C}_{6} \mathrm{H}_{4}, 20
$$$$
A^{r}=4^{-} \mathrm{MeOC}_{6} \mathrm{H}_{4}, 21
$$<smiles>CCOCCCPCP(I)P(I)I</smiles>

22

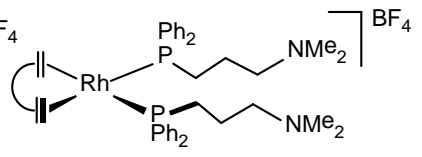

23

Chart 3. Structures of Type II $\left[\mathrm{Rh}(\mathrm{cod})(\mathrm{P} \cap \mathrm{Z})_{2}\right][\mathrm{X}](\mathbf{1 4}-\mathbf{2 3})$ complexes.

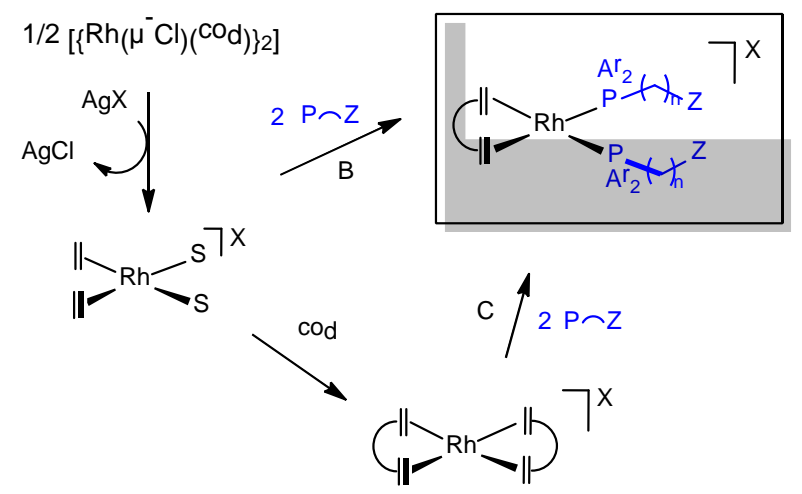

Scheme 3. Synthetic routes for the preparation of Type II $\left[R h(\operatorname{cod})(P \cap Z)_{2}\right][X]$ complexes $\left(\mathrm{S}=\mathrm{Me}_{2} \mathrm{CO}\right.$ or tetrahydrofuran).
In order to get detailed information on the structural parameters of these complexes, the X-ray determination of the molecular structure of a representative compound, [Rh(cod) $\left.\left\{\mathrm{Ph}_{2} \mathrm{P}\left(\mathrm{CH}_{2}\right)_{3} \mathrm{OEt}\right\}_{2}\right]\left[\mathrm{BF}_{4}\right]$ (19a), was carried out. A view of the molecular structure of the metal cationic complex of 19a is shown in Figure 3. The most significant structural features concern the small bite angle of the coordinated cod ligand, 84.96(13) $)^{\circ}$, and the high P-Rh-P angle observed between the two sterically demanding phosphines, $93.01(4)^{\circ}$, both parameters clearly different from the ideal value expected for a square-planar coordination. Compared to the structural data observed in the $\kappa^{2}$ $P, O$ chelated complexes $\mathbf{1}, \mathbf{2}$ and $\mathbf{8}$, it is remarkable the longer Rh-P bond distances observed in 19a, (2.3388 and 2.3493(12) $\AA$ ), and the similarity of all Rh-C(olefin) bond distances (all in the range 2.2047-2.2285(5) $\AA$ ).

\begin{tabular}{l} 
Table 3. $\left.{ }^{13} \mathrm{C}_{\{1}^{1} \mathrm{H}\right\}$ NMR chemical shifts for the methyl or methylenic groups \\
bonded to the heteroatom in selected Type I and II complexes. \\
\cline { 2 - 4 }
\end{tabular}

[a] Values for $\mathrm{Ar}=4-\mathrm{MeC}_{6} \mathrm{H}_{4}$ are given in parenthesis.

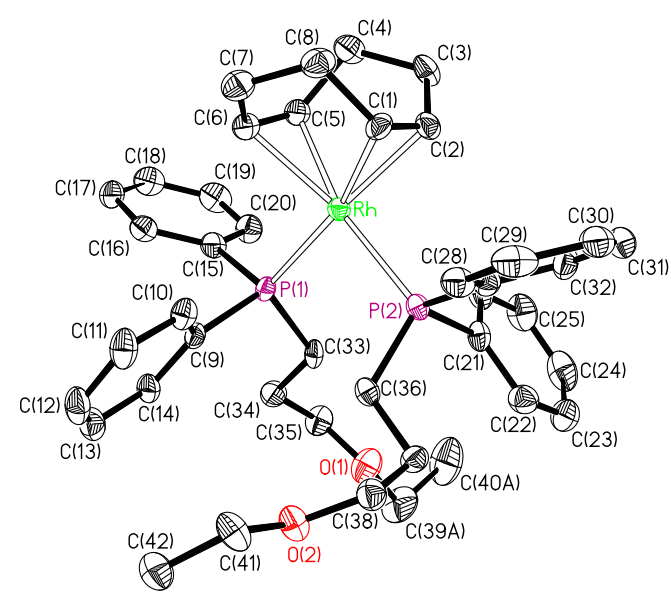

Figure 3. Molecular structure for the cation of 19a. Hydrogen atoms have been omitted for clarity. Selected bond lengths $(\AA)$ and angles $\left({ }^{\circ}\right)$ : Rh-P(1) 2.3492(12) $\mathrm{Rh}-\mathrm{P}(2)$ 2.3388(12), Rh-C(1) 2.229(5), Rh-C(2) 2.204 (5), Rh-M(1) 2.103(3), $\mathrm{Rh}-\mathrm{C}(5)$ 2.218(5), Rh-C(6) 2.227(5), Rh-M(2) 2.111(4), P(1)-Rh-P(2) 93.01(4), $\mathrm{M}(1)-\mathrm{Rh}-\mathrm{M}(2)$ 84.96(13), P(1)-Rh-M(2) 90.81(9), P(2)-Rh-M(1) 91.22(9). M(1) and $M(2)$ represent the midpoints of the olefinic bonds $C(1)-C(2)$ and $C(5)-C(6)$, respectively. 
The cationic cyclooctadiene free $\mathrm{Rh}(\mathrm{I})$ complexes containing two 3-ethoxypropyl functionalized phosphines have been synthesized from $\left[\mathrm{Rh}(\mu-\mathrm{Cl})(\mathrm{Coe})_{2}\right]_{2}$ through the intermediate solvato complex $\left[\mathrm{Rh}(\mathrm{coe})_{2}(\text { acetone })_{2}\right]^{+}$. Reaction of this species, generated in situ, with two equivalents of the suitable phosphine in acetone at $273 \mathrm{~K}$ gave red solutions of the complexes (Scheme 4). These compounds were isolated as red crystals by slow diffusion of diethyl ether into saturated solutions of the complexes in tetrahydrofuran. The compounds are air sensitive, both in solution and in solid state, and slowly decompose in chlorinated solvents.

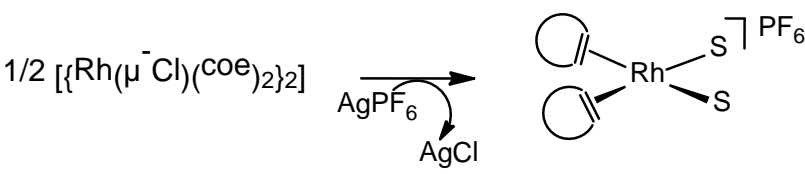

$$
\begin{aligned}
& 2 \mathrm{Ar}_{2} \mathrm{P}\left(\mathrm{CH}_{2}\right)_{3} \mathrm{OEt}
\end{aligned}
$$

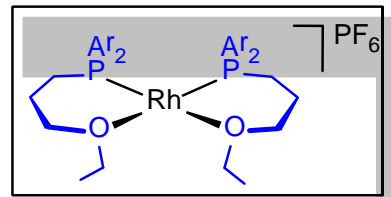

$$
\begin{aligned}
& A^{r}=P^{\prime} 24 \\
& \mathrm{Ar}={ }^{-} \mathrm{MeC}_{6} \mathrm{H}_{4}, 25 \\
& A^{r}={ }_{4}^{-} \mathrm{MeOC}_{6} \mathrm{H}_{4}, 26
\end{aligned}
$$

Scheme 4. Synthetic route for the preparation of Type III $\left[R h(P \cap Z)_{2}\right]\left[P F_{6}\right](24-$ 26) complex $\left(\mathrm{S}=\mathrm{Me}_{2} \mathrm{CO}\right)$.

As it was observed for the previously $X$-ray determined structure of $\mathbf{2 4},{ }^{24}$ the structural analysis of $\mathbf{2 5}$ reveals the expected square-planar coordination around the rhodium atom with a cis disposition for the two $\kappa^{2}-P, O$ coordinated chelate etherphosphine ligands (Figure 4). As it was suggested for 24, the presence of a clear $\pi-\pi$ intramolecular interaction ( $\mathrm{G} \cdots \mathrm{G}$ 3.939(3) $\AA$, Ph-Ph dihedral angle $7.4(2)^{\circ}$ in 24) also observed in 25 (G-G 3.804(2) $\AA$, $\left.\mathrm{Ph}-\mathrm{Ph} 2.2(2)^{\circ}\right)$, between two phenyl groups of the two phosphines, could be at least partially responsible for this particular cis arrangement. ${ }^{[30]}$ The shorter $G \cdots G$ distances determined in $\mathbf{2 5}$ may be due to the increased electron density available at the phenyl ring as a result of the presence of methyl substituents. The mutual cis disposition of the two hemilabile ether-functionalized phosphine ligands is also consistent with the antisymbiotic effect between oxygen and phosphorous atoms ${ }^{[31]}$ Thus, the trans configuration of a phosphorous atom, with high trans influence (soft), to an oxygen atom, with low trans influence (hard), clearly reduces the competition for the metal $d$-electrons resulting in a net stabilizing effect. ${ }^{[32]}$ The analysis of the puckering parameters for the two metallocycles shows the existence of ${ }^{1} \mathrm{C}_{4}$ chair conformations ${ }^{[33]}$ with the rhodium and the carbons $\mathrm{C}(2) / \mathrm{C}(7)$ situated out of the mean planes calculated for the two rings.

The spectroscopic data for complexes 24-26 are in agreement with the square planar structure of nearly $C_{2}$ symmetry found in the solid state. The resonances in the ${ }^{1} \mathrm{H}$ NMR spectra are somewhat broad at room temperature depending on the coordinating ability of the solvent. The existence of conformational equilibria, the dynamic chelating "on-off" coordination of the ligands or even, the possible solvent coordination could account for this observation.

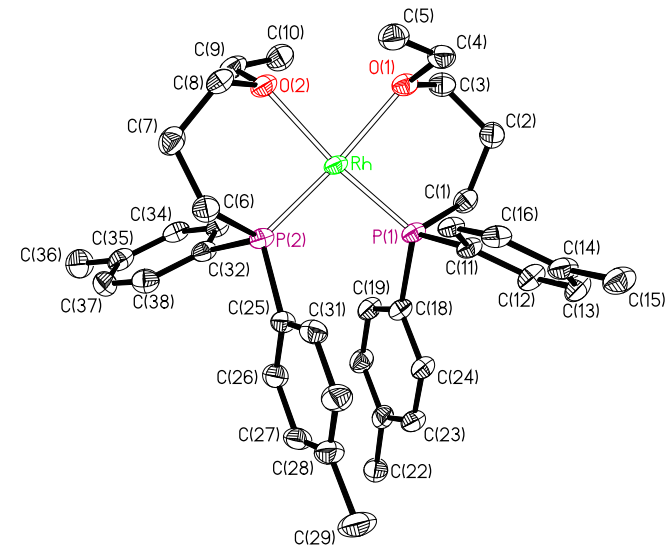

Figure 4. Molecular diagram of the cationic metal complex 25. Hydrogen atoms have been omitted for clarity. Selected bond lengths $(\AA)$ and angles $\left(^{\circ}\right)$ : Rh-P(1) 2.1860(8), $\quad \mathrm{Rh}-\mathrm{P}(2) \quad 2.1863(9), \quad \mathrm{Rh}-\mathrm{O}(1) \quad 2.198(2), \quad \mathrm{Rh}-\mathrm{O}(2) \quad 2.200(2)$, $\mathrm{O}(1)-\mathrm{Rh}-\mathrm{P}(1) \quad 88.82(6), \quad \mathrm{O}(2)-\mathrm{Rh}-\mathrm{P}(2) \quad 90.24(6), \quad \mathrm{P}(1)-\mathrm{Rh}-\mathrm{P}(2) \quad 96.77(3)$ $\mathrm{O}(1)-\mathrm{Rh}-\mathrm{O}(2)$ 84.36(8), $\mathrm{P}(1)-\mathrm{Rh}-\mathrm{O}(2)$ 172.90(6), $\mathrm{P}(2)-\mathrm{Rh}-\mathrm{O}(1)$ 171.42(6)

The ${ }^{31} \mathrm{P}\left\{{ }^{1} \mathrm{H}\right\}$ NMR of the complexes features a doublet at $\delta \approx$ $43 \mathrm{ppm}$ with $\mathrm{J}_{\mathrm{Rh}-\mathrm{P}}$ coupling constants of ca. $200 \mathrm{~Hz}$. Theses values are higher than those observed for the precedent types of compounds and probably reflect the coordination of the -OEt in trans. Finally, a diagnostic for the $\kappa^{2}-P, O$ coordination mode of these ligands is found in the ${ }^{13} \mathrm{C}\left\{{ }^{1} \mathrm{H}\right\}$ NMR spectra as the resonance for $>\mathrm{CH}_{2}$ of the ethyl group is shifted, ca. $5 \mathrm{ppm}$ to lower field compared to complexes containing $\kappa-P$ coordinated phosphine ligands with uncoordinated -OEt groups.

\section{Catalytic activity of $[\mathrm{Rh}(\mathrm{cod})(\mathrm{P} \cap \mathrm{Z})]\left[\mathrm{BF}_{4}\right]($ Type I) complexes.}

\section{Influence of the donor set on the hemilabile fragment}

The catalytic activity may be related with the potential dynamic "on-off" effect of the hemilabile ligand and consequently with the strength of the rhodium-heteroatom bond. The catalytic activity has been evaluated for compounds $\mathbf{1}, \mathbf{1 1}$ and $\mathbf{1 3}$ having hemilabile ligands with 2-methoxy-ethyl, 2-dimethylamino-ethyl and 2tiomethyl-ethyl groups, respectively. These catalysts are structurally related but have different $\mathrm{O}, \mathrm{N}$, and $\mathrm{S}$ donor atoms in the hemilabile fragment. The observed catalytic activity (expressed as piperidine conversion in \%) follows the order $\mathbf{1}>\mathbf{1 1}$ $>13$ (Table 4, entries 1-3) which suggests a correlation between catalytic activity and the lability of the rhodium heteroatom bond. Thus, flexible ether functionalized hemilabile phosphine have revealed as the most efficient ancillary ligands.

It is surprisingly the low activity shown by catalyst $\mathbf{1 1}$ with a dimethylamino functionalized phosphine. This contrasts with the moderate activities shown in the intramolecular hydroamination of alkenes by the systems $\left[\mathrm{Rh}(\mathrm{cod})_{2}\right]\left[\mathrm{BF}_{4}\right]$ or $\left[\mathrm{Rh}(\mathrm{cod})\left(\mathrm{NCCH}_{3}\right)_{2}\right]\left[\mathrm{BF}_{4}\right]$ in combination with aminobiarylphosphine ligands as DavePhos (2-dicyclohexylphosphine-2'-(N,N-dimethylamino)biphenyl),

Kenphos (2-dicyclohexylphosphine-2'-(N,N-dimethylamino)binapthyl) or chiral ligands inspired in the later. ${ }^{[4,34]}$ However, it is well known that the intramolecular hydroamination is entropically favored over the intermolecular process.

Influence of the hydrocarbon chain length (n) and the substituent in the hemilabile fragment $(R)$. 
The influence of the hydrocarbon chain length and the substituent at the heteroatom of the hemilabile fragment have been evaluated with complexes having the efficient ether-functionalized phosphine ligands coordinated in a $\kappa^{2}-P, O$ fashion, as in complexes $1(n=2)$ and $4(\mathrm{n}=3)$, and $\left[\mathrm{Rh}\left(\mathrm{NCCH}_{3}\right)(\mathrm{cod})\left\{\mathrm{Ph}_{2} \mathrm{P}\left(\mathrm{CH}_{2}\right) \mathrm{OMe}\right\}\right]\left[\mathrm{BF}_{4}\right]$ (27) with a ligand $\kappa-P$ coordinated $(\mathrm{n}=1)$. Complex 2 , with a sixmembered metalacycle ring $(n=3)$, exhibits a superior catalytic activity (Table 4, entries 1,4-5). The same trend has been observed when the catalytic activity of complexes $\mathbf{5}$ and $\mathbf{8}$ was compared ( $\mathrm{R}=\mathrm{Et}$, entries 6 and 7 ). Interestingly, good selectivity in the enamine product, over $98 \%$, was obtained in most cases. On the other hand, complex 27 having a methoxy-methyl functionalized ligand with the potential for a strained fourmembered metalacycle ring has much less catalytic activity. The observed correlation between the size of the metalacycle ring and the catalytic activity could be an effect of the greater stability of the five-membered $(n=2)$ metalacycle ring. However, it is important to notice that the flexibility of the hemilabile ligands with $n=3$ could also facilitate the dynamic "on-off" protection for the metal center.

The substituent at the heteroatom of the donor set on the hemilabile fragment has also an influence on the catalytic activity. The catalytic activity of complexes $\mathbf{4 , 8}$ and $\mathbf{2 8}$ having the ligands $\mathrm{Ph}_{2} \mathrm{P}\left(\mathrm{CH}_{2}\right)_{3} \mathrm{OR}$ with $\mathrm{R}=\mathrm{Me}$, Et, $n \mathrm{Bu}$; respectively, follows the order $\mathbf{8}>\mathbf{4}>\mathbf{2 8}$ (Table 4, entries 5, 7-8), showing the superior performance of catalyst precursors having the ethoxyfunctionalized hemilabile phosphine. Thus, the hemilabile ligand have a decisive influence on the catalytic activity and the catalyst precursor 8 having the ligand (3-ethoxypropyl)diphenilphosphine $(n=3, R=E t)$ is the most active in this series (Table 4, Fig. 5). However, the hemilabile ligand have little influence in the selectivity as the selectivity to (E)-1-styrylpiperidine is, in most cases, superior to $98 \%$.

The rationalization of these results is not simple. In principle, the small increase in the electron density in the heteroatom introduced by -Et compared to -Me should increase the coordination ability of the hemilabile fragment. However, the steric effects associated with the protection/unprotection of the catalyst could also play a role and, in fact, the catalyst precursor $28(\mathrm{R}=$ $n \mathrm{Bu}$ ) is the less active in the series.

\section{$<<$ Please, find the Table 4 at the end of the document $>>$}

the table is bigger than one column

Influence of the substituent in the aryl groups $(X)$ of the hemilabile phosphine.

The introduction of substituents in the phenyl groups allows for the fine tunning of the electronic and the steric properties of the hemilabile phosphine ligands that can also influence the activity of the catalyst precursors. In general, the introduction of electron donating groups in para position of the phenyl groups results in an increase in the catalytic activity. In particular, catalyst $\mathbf{9}$, with the ligand $\left(4-\mathrm{CH}_{3} \mathrm{C}_{6} \mathrm{H}_{4}\right)_{2} \mathrm{P}\left(\mathrm{CH}_{2}\right)_{3} \mathrm{OEt}$, increase the piperidine conversion from $75 \%$ (Table 4 , entry 7 , catalyst 8 ) to $88 \%$ in $20 \mathrm{~h}$ although with a slightly decrease in the chemoselectivity (96\%, entry 9). On the contrary, electron withdrawing groups in para position, as trifluoromethyl, strongly inhibited the catalytic activity as it is shown with catalysts $[\mathrm{Rh}(\operatorname{cod})\{(4-$ $\left.\left.\left.\mathrm{CF}_{3} \mathrm{C}_{6} \mathrm{H}_{4}\right)_{2} \mathrm{P}\left(\mathrm{CH}_{2}\right)_{\mathrm{n}} \mathrm{OEt}\right\}\right]\left[\mathrm{BF}_{4}\right](\mathrm{n}=2,7 ; \mathrm{n}=3,10)$ (Table 4, entries $10,12)$. On the other hand, the presence of a methyl group in ortho position of the phenyl rings, catalyst $[\mathrm{Rh}(\mathrm{cod})\{(2-$ $\left.\left.\left.\mathrm{CH}_{3} \mathrm{C}_{6} \mathrm{H}_{4}\right)_{2} \mathrm{P}\left(\mathrm{CH}_{2}\right)_{2} \mathrm{OMe}\right\}\right]\left[\mathrm{BF}_{4}\right]$ (3), also inhibited the catalytic activity probably as a consequence of the steric influence (entry 13).

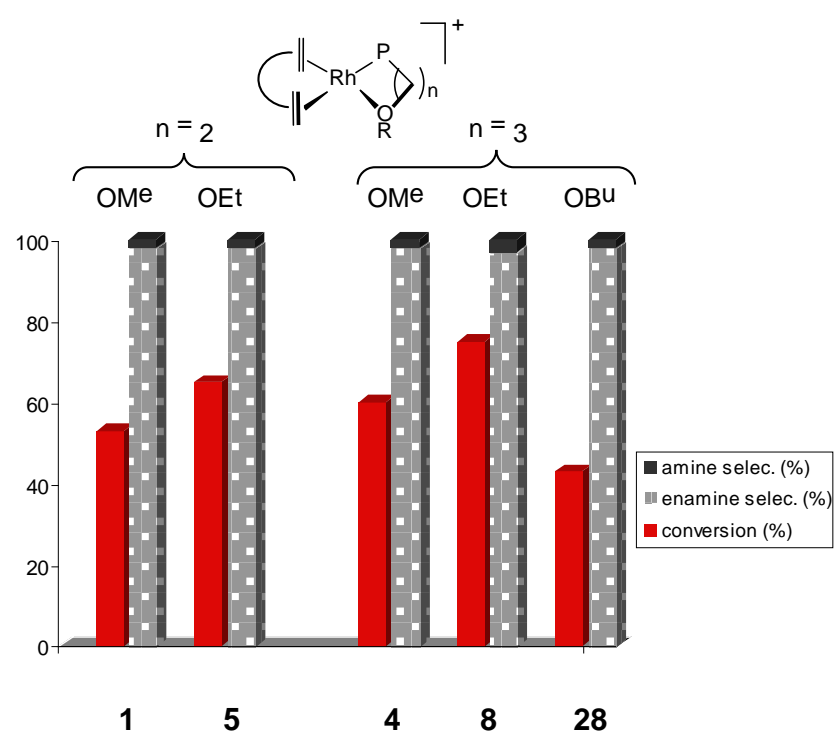

Figure 5. Influence of the hemilabile ligand $\mathrm{Ph}_{2} \mathrm{P}\left(\mathrm{CH}_{2}\right)_{n} \mathrm{OR}, \mathrm{n}$ and $\mathrm{R}$, in the oxidative amination of styrene with piperidine by different Type I catalyst precursors (reaction time $20 \mathrm{~h}$ ).

The increase of the electronic density at the rhodium center through the introduction of electron donating groups in the phosphine fragment enhances the catalytic activity. The observed trend is in agreement with the results reported by Beller et ${ }^{a l} .{ }^{[35]}$ in the hydroamination of styrene by piperidine catalyzed by the systems $\left[\mathrm{Rh}(\operatorname{cod})_{2}\right]\left[\mathrm{BF}_{4}\right] / 2 \mathrm{PR}_{3}$ using the ligands $\mathrm{Ph}_{2} \mathrm{P}\left(2-\mathrm{C}_{6} \mathrm{H}_{4} \mathrm{OEt}\right)$ and $\mathrm{Ph}_{2} \mathrm{P}\left(4-\mathrm{C}_{6} \mathrm{H}_{4} \mathrm{OMe}\right)$, the former a rigid ligand structurally related to the flexible $\mathrm{Ph}_{2} \mathrm{P}\left(\mathrm{CH}_{2}\right)_{2} \mathrm{OMe}$. However, the molecular structure of the complex $\left[\mathrm{Rh}(\mathrm{cod})\left\{\left(4-\mathrm{CH}_{3} \mathrm{C}_{6} \mathrm{H}_{4}\right)_{2} \mathrm{P}\left(\mathrm{CH}_{2}\right)_{3} \mathrm{OEt}\right\}\right]$ $\left[\mathrm{BF}_{4}\right]^{-} \mathrm{Me}_{2} \mathrm{CO}(9 \mathrm{~b})$, with an uncoordinated ethoxypropyl fragment due to the coordination of an acetone molecule, suggests the destabilization of the six member metalacycle, prompting the opening of the ring and therefore enhancing the hemilabile character of the ligand.

\section{Catalytic activity of $\left[\mathrm{Rh}(\mathrm{cod})(\mathrm{P} \cap \mathrm{O})_{2}\right][\mathrm{X}]$ (Type II) complexes.}

The preceding results show the positive effect on the catalytic activity of the presence of one bidentate chelate etherfunctionalized phosphine ligands in the rhodium catalyst precursor We have also explore the catalytic activity of Type II complexes, $\left[\mathrm{Rh}(\operatorname{cod})(\mathrm{P} \cap \mathrm{O})_{2}\right][\mathrm{X}]$, that contain two ether-functionalized phosphine ligands $\kappa-P$ coordinated. A comparative study of the catalytic activity of related complexes having the same hemilabile ligand, $\left[\mathrm{Rh}(\mathrm{cod})\left\{\mathrm{Ar}_{2} \mathrm{P}\left(\mathrm{CH}_{2}\right)_{n} \mathrm{OR}\right\}\right] \quad$ (Type I) and $\left[\mathrm{Rh}(\mathrm{cod})\left\{\mathrm{Ar}_{2} \mathrm{P}\left(\mathrm{CH}_{2}\right)_{n} \mathrm{OR}\right\}_{2}\right]$ (Type II), is shown in Table 5 and Figure 6.

As it can be seen, there is a general increase in catalytic activity that is impressive in some cases reaching over $80 \%$ of conversion in just $4 \mathrm{~h}$. In the methoxy-functionalized series (entries 1-5) it is notable the catalytic activity exhibited by catalyst 16, $92 \%$ conversion in $20 \mathrm{~h}$ (entry 5), with the hemilabile ligand (4$\left.\mathrm{CH}_{3} \mathrm{C}_{6} \mathrm{H}_{4}\right)_{2} \mathrm{P}\left(\mathrm{CH}_{2}\right)_{3} \mathrm{OMe}$, having a -Me group in para position of the phenyl groups. A similar upsurge in the catalytic activity was observed in the 2-ethoxyethyl series (entries 6-8) being catalyst 18, with a $p$-Me- substituent, the most active. However, the more efficient catalysts were found in the 3-ethoxypropyl series. Catalysts 19a and 20 with the ligands $\mathrm{Ph}_{2} \mathrm{P}\left(\mathrm{CH}_{2}\right)_{3} \mathrm{OEt}$ and (4- 
$\left.\mathrm{CH}_{3} \mathrm{C}_{6} \mathrm{H}_{4}\right)_{2} \mathrm{P}\left(\mathrm{CH}_{2}\right)_{3} \mathrm{OEt}$, respectively, gave piperine conversions higher than $95 \%$ in only $8 \mathrm{~h}$ (entries 10 and 12 ).

Surprisingly, catalyst $\mathbf{2 1}$ having a -OMe group in para position of the phenyl groups is significantly less active than $\mathbf{2 0}$, in spite of the stronger electron donating character of the methoxo group (entries 12-13). This result is out of the general observed trend, and suggests that the catalytic activity of these systems is determined by the interplay of subtle electronic and steric effects in key intermediate catalytic species.

\section{$<<$ Please, find the Table 5 at the end of the document $>>$} the table is bigger than one column

The substituent in the -OR donor set in Type II complexes also have a decisive influence on the catalyst performance. The catalytic activity of complexes having the ligands $\mathrm{Ph}_{2} \mathrm{P}\left(\mathrm{CH}_{2}\right)_{3} \mathrm{OR}$ $(\mathrm{R}=\mathrm{Me}, \mathrm{Et}$ and $n-\mathrm{Bu})$ follows the order 19a $(\mathrm{R}=\mathrm{Et})>22(\mathrm{R}=n-$ $\mathrm{Bu})>15(\mathrm{R}=\mathrm{Me})$ (entries 4, 10 and 15). The comparison of the catalytic activity of complexes 18 and 20, $[\mathrm{Rh}(\operatorname{cod})\{(4-$ $\left.\left.\left.\mathrm{CH}_{3} \mathrm{C}_{6} \mathrm{H}_{4}\right)_{2} \mathrm{P}\left(\mathrm{CH}_{2}\right)_{n} \mathrm{OEt}\right\}_{2}\right]^{+}(\mathbf{1 8}, \mathrm{n}=2 ; \mathbf{2 0}, \mathrm{n}=3)$, confirm the fact that the catalytic systems based on hemilabile ligands with the potential for the formation of six-membered metalacycles $(n=3)$ are far more active than those of five-membered metalacycles ( $n$ $=2$ ) (entries 8 and 12).

The time dependence of the catalytic oxidative amination of styrene with piperidine by complexes $[\mathrm{Rh}(\operatorname{cod})\{(4-$ $\left.\left.\left.\mathrm{RC}_{6} \mathrm{H}_{4}\right)_{2} \mathrm{P}\left(\mathrm{CH}_{2}\right)_{3} \mathrm{OEt}\right\}\right]^{+}(\mathbf{8}, \mathrm{R}=\mathrm{H} ; 9 \mathrm{R}=\mathrm{Me})$ and $[\mathrm{Rh}(\operatorname{cod})\{(4-$ $\left.\left.\left.\mathrm{RC}_{6} \mathrm{H}_{4}\right)_{2} \mathrm{P}\left(\mathrm{CH}_{2}\right)_{3} \mathrm{OEt}\right\}_{2}\right]^{+}(\mathbf{1 9 a}, \mathrm{R}=\mathrm{H} ; 20 \mathrm{R}=\mathrm{Me})$ is shown in Figure 6 and shows the positive effect of the introduction of a Me- group in the para position in both type of complexes or the change of the methyl sustituent in the hemilabile fragment.

The influence of the anion in the catalytic activity has been studied with complex $\left[\mathrm{Rh}(\mathrm{cod})\left\{\mathrm{Ph}_{2} \mathrm{P}\left(\mathrm{CH}_{2}\right)_{3} \mathrm{OEt}\right\}_{2}\right][\mathrm{X}]\left(\mathrm{X}=\mathrm{BF} \mathrm{F}_{4}, \mathbf{1 9 a}\right.$; $\left.\mathrm{PF}_{6}, 19 \mathbf{b} ; \mathrm{SbF}_{6}, 19 \mathrm{c}\right)$. The catalytic activity slightly decreases in the sequence $\mathrm{PF}_{6}^{-}>\mathrm{BF}_{4}^{-}>\mathrm{SbF}_{6}^{-}$(Table 5, entries 10-12) what is accordance to previous observations in intra- or intermolecular hydroamination with mononuclear rhodium(I), palladium, gold or platinum. ${ }^{[5 b, 36]}$ The hexafluorophosphate cationic complex allows to reach conversions of 92 and $97 \%$ at $4 \mathrm{~h}$ and $8 \mathrm{~h}$, respectively, with a $96 \%$ of selectivity to enamine.

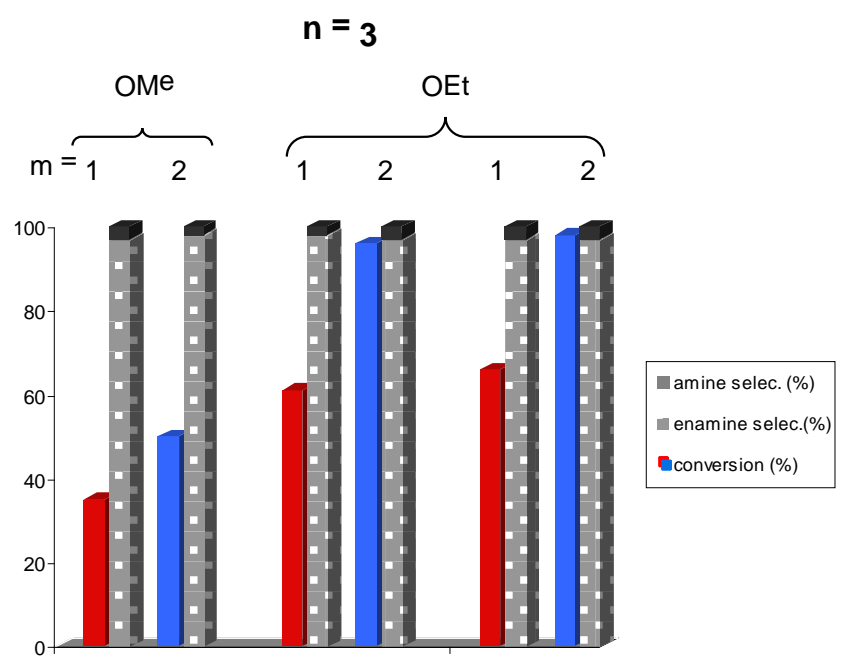

$\begin{array}{llllll}4 & 15 & 8 & 19 a & 9 & 20\end{array}$

Figure 6. Influence of the number of hemilabile phosphines $\mathrm{Ar}_{2} \mathrm{P}\left(\mathrm{CH}_{2}\right)_{3} \mathrm{OR}$ in the oxidative amination of styrene with piperidine by different Type I and Type II catalyst precursors (reaction time $8 \mathrm{~h}$ ).

\section{Catalytic activity of $\left[\mathrm{Rh}(\mathrm{P} \cap \mathrm{O})_{2}\right]\left[\mathrm{PF}_{6}\right](\mathrm{Type} \mathrm{III})$ complexes.}

The investigation of some of the catalytic solutions by GC/MS using Type I and II complexes as catalysts showed a peak with a $\mathrm{m} / \mathrm{z}$ ratio of 191 that corresponds to 1-(cycloocta-1,5-dien-1yl)piperidine. Thus, it seems that the oxidative amination of the coordinated 1,5-cyclooctadiene ligand could be a previous requirement for the generation of the catalytic active species. This observation prompted us to synthesize cyclooctadiene free Type III complexes and study their catalytic activity.

The catalytic activity exhibited by complexes $[\mathrm{Rh}\{(4-$ $\left.\left.\left.\mathrm{RC}_{6} \mathrm{H}_{4}\right)_{2} \mathrm{P}\left(\mathrm{CH}_{2}\right)_{3} \mathrm{OEt}\right\}_{2}\right]\left[\mathrm{PF}_{6}\right](\mathbf{2 4 - 2 6 )}$ is remarkable reaching up to a $90 \%$ conversion in just one hour (Table 6) with an excellent selectivity to the enamine (96\%). As it was expected, complex 25 $(R=M e)$ is slightly more active than $24(R=H)$ being $26(R=$ $\mathrm{OMe})$ the less active catalyst precursor in this series. The profile for the oxidative amination of styrene (piperidine conversion vs time) for selected complexes having $\left(4-\mathrm{R}-\mathrm{C}_{6} \mathrm{H}_{4}\right)_{2} \mathrm{P}\left(\mathrm{CH}_{2}\right)_{3} \mathrm{OEt}(\mathrm{R}=$ $\mathrm{H}, \mathrm{CH}_{3}$ ) ligands is shown in Figure 7. Type III complexes exhibited an outstanding catalytic activity with TOFs $\left(\mathrm{h}^{-1}\right)$ values at $50 \%$ piperidine conversion, estimated from conversion profile curves, of $67(24, \mathrm{R}=\mathrm{H})$ and $80\left(25, \mathrm{R}=\mathrm{CH}_{3}\right)$. On the other hand, the catalytic activity shown by Type II complexes, $\left[\mathrm{Rh}(\mathrm{cod})\left\{\mathrm{Ar}_{2} \mathrm{P}\left(\mathrm{CH}_{2}\right)_{3} \mathrm{OEt}\right\}_{2}\right]^{+}$, is also remarkable, with TOFs $\left(\mathrm{h}^{-1}\right)$ of $12(19 a, R=H)$ and $14\left(20, R=C_{3}\right)$, much higher that those of Type I complexes $3.5(8, \mathrm{R}=\mathrm{H})$ and $4\left(\mathbf{9}, \mathrm{R}=\mathrm{CH}_{3}\right)$.

\section{$<<$ Please, find the Table 6 at the end of the document $>>$ the table is bigger than one column}

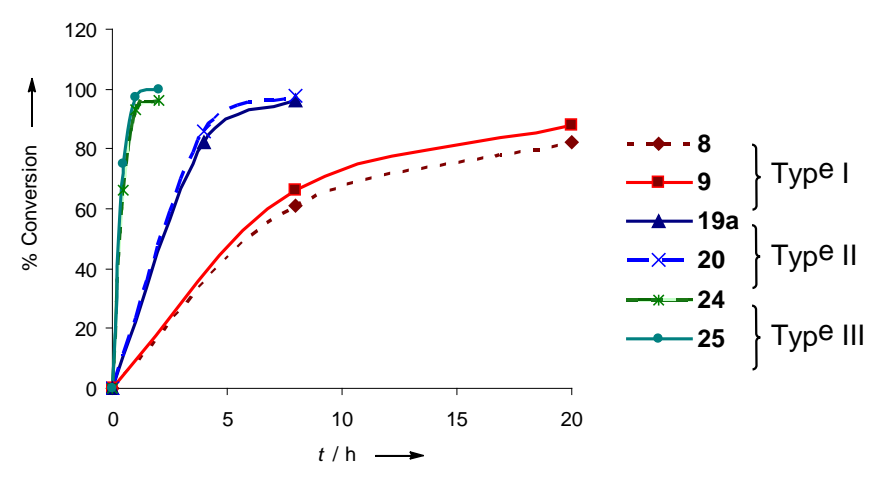

Figure 7. Conversion profile for the oxidative amination of styrene with piperidine profile catalyzed by selected $\left[\mathrm{Rh}(\mathrm{cod})\left\{\left(4-\mathrm{R}-\mathrm{C}_{6} \mathrm{H}_{4}\right)_{2} \mathrm{P}\left(\mathrm{CH}_{2}\right)_{3} \mathrm{OEt}\right\}_{\mathrm{m}}\right]^{+}$Type I $(\mathrm{m}=1$, 8 and 9), Type II $\left(\mathrm{m}=2, \mathbf{1 9 a}\right.$ and 20) and Type III $\left.\operatorname{Rh}\left\{\left(4-\mathrm{RC}_{6} \mathrm{H}_{4}\right)_{2} \mathrm{P}\left(\mathrm{CH}_{2}\right)_{3} \mathrm{OEt}\right\}_{2}\right]$ (24 and 25) complexes. Reaction conditions: styrene/piperidine/cat. 160/40/1; $[R h]=0.01 \mathrm{M}$ in $\mathrm{THF}, 80^{\circ} \mathrm{C}$.

The complexes $\left[\mathrm{Rh}\left\{\left(4-\mathrm{RC}_{6} \mathrm{H}_{4}\right)_{2} \mathrm{P}\left(\mathrm{CH}_{2}\right)_{3} \mathrm{OEt}\right\}_{2}\right]\left[\mathrm{PF}_{6}\right](\mathrm{R}=\mathrm{H}, \mathbf{2 4}$; Me 25) were found to be active in other solvents as toluene or dioxane. The attained conversions by $\mathbf{2 5}$, under the standard conditions, were 98\% (THF), 83\% (toluene) and 71\% (dioxane), with similar enamine selectivity. In general, although good conversions were also obtained in toluene the amount of ethylbenzene exceeds that of enamine by $10 \% .{ }^{17}$ The low enamine/ethylbenzene ratio of $\approx 0.83$ could be due to the participation of the enamine in the amination processes to give undetected amine by-products.

The temperature has a strong influence on the catalytic activity but none in the enamine selectivity that is over $96 \%$ in the range of $60-100{ }^{\circ} \mathrm{C}$. Catalyst precursors 24 and 25 showed reasonable catalytic activities at $60{ }^{\circ} \mathrm{C}$ with conversions to $(E)-1$ - 
styrylpiperidine of $44 \%$ and $50 \%$, respectively, in $2 \mathrm{~h}$. The catalytic activity sharply increases with temperature and, for example, an increase in the conversion from $75 \%$ to $88 \%(0.5 \mathrm{~h})$ was observed for complex 25 when the temperature was raised from 80 to $100{ }^{\circ} \mathrm{C}$. However, catalyst deactivation was observed at temperatures higher than $80^{\circ} \mathrm{C}$.

\section{Conclusions}

Functionalized phosphine ligands of hemilabile character have a positive influence on the catalytic activity of rhodium/phosphine systems in the intermolecular hydroamination reaction. Under the optimized reaction conditions, cationic square planar rhodium(I) complexes containing highly flexible hemilabile phosphine ligands efficiently catalyzed the anti-Markovnikov oxidative amination of styrene with piperidine with excellent chemo- and regioselectivity to give $(E)$-1-styrylpiperidine. Interestingly, a remarkable catalyst efficiency has been observed with the systems based on P,Ofunctionalized arylphosphine ligands with a 2-alkoxoethyl or 3alkoxopropyl hemilabile moiety, $\mathrm{Ar}_{2} \mathrm{P}\left(\mathrm{CH}_{2}\right)_{n} \mathrm{OR}(\mathrm{n}=2,3$; $\mathrm{R}=\mathrm{Me}$, $\mathrm{Et}, n \mathrm{Bu})$.

The catalyst structure has a strong influence on the catalytic activity. The activity exhibited by complexes featuring two $\kappa^{1}-\mathrm{P}$ coordinated hemilabile ligands, $\left[\mathrm{Rh}(\mathrm{cod})\left\{\mathrm{Ar}_{2} \mathrm{P}\left(\mathrm{CH}_{2}\right)_{n} \mathrm{OR}\right\}_{2}\right]^{+}$, is much higher than that shown by complexes having only one hemilabile ligand $\kappa^{2}-\mathrm{P}, \mathrm{O}$ coordinated, $\left[\mathrm{Rh}(\mathrm{cod})\left\{\mathrm{Ar}_{2} \mathrm{P}\left(\mathrm{CH}_{2}\right)_{n} \mathrm{OR}\right\}\right]^{+}$. Interestingly, bis-phosphine complexes $\left[\mathrm{Rh}\left\{\mathrm{Ar}_{2} \mathrm{P}\left(\mathrm{CH}_{2}\right)_{n} \mathrm{OR}\right\}_{2}\right]^{+}$, containing two $\kappa^{2}-\mathrm{P}, \mathrm{O}$ coordinated ligands in a cis disposition, showed an outstandingly high catalytic activity. The fine tuning of the electronic properties of the hemilabile phosphines have shown that the presence of electron donating groups in para position of the aryl moiety results in an increase in the catalytic activity. Complexes $\left[\mathrm{Rh}\left\{\left(4-\mathrm{R}-\mathrm{C}_{6} \mathrm{H}_{4}\right)_{2} \mathrm{P}\left(\mathrm{CH}_{2}\right)_{3} \mathrm{OEt}\right\}_{2}\right]\left[\mathrm{PF}_{6}\right](\mathrm{R}=\mathrm{H}, \mathrm{Me}, \mathrm{OMe})$, with 3-ethoxypropyl functionalized phosphine ligands, showed unprecedented turnover frequencies up to $80 \mathrm{~h}^{-1}(\mathrm{R}=\mathrm{Me})$ with excellent enamine selectivity (96\%).

The superior performance of catalyst precursors having 3ethoxypropyl functionalized phosphines could be a consequence of the ability of these ligands for a dynamic "on-off" effect in key catalytic intermediates. Important features of these ligands are their potential for a weak interaction with the rhodium center through the oxygen atom forming a six-membered metallocycle ring, and the flexibility imparted by the trimethylene chain. In addition, the steric and electronic effects introduced by the ethyl group of the 3-ethoxypropyl moiety seem to be also important in the protection/unprotection of active sites in the catalysts.

\section{Experimental Section}

\section{General Remarks}

\section{Synthesis.}

Reactions were carried out under exclusion of air by using standard Schlenk techniques. Solvents were dried by known procedures and distilled under argon just prior to use, or obtained from a Solvent Purification System (Innovative Technologies). $\mathrm{CDCl}_{3}, \mathrm{CD}_{2} \mathrm{Cl}_{2}$, THF- $d_{8}$ (Euriso-top) were dried using activated molecular sieves. Standard literature procedures were used to prepare the starting materials $[\mathrm{Rh}(\mu-\mathrm{Cl})(\mathrm{cod})]_{2}{ }^{\left[{ }^{37]}\right]}\left[\mathrm{Rh}(\mathrm{cod})_{2}\right] \mathrm{X},\left[\mathrm{Rh}(\mathrm{cod})\left(\mathrm{NCCH}_{3}\right)_{2}\right][\mathrm{X}]^{[38]}$ and $[\mathrm{Rh}(\mu-$ $\mathrm{Cl}$ (coe) $\left.)_{2}\right]_{2}{ }^{[39]}$ The functionalized hemilabile phosphines, $\mathrm{R}_{2} \mathrm{P}\left(\mathrm{CH}_{2}\right)_{n} \mathrm{Z}$, were prepared following published methods (see supporting information). ${ }^{[25]}$

\section{General Procedure for Hydroamination Catalytic Experiments.}

The catalytic hydroamination reactions were carried out under an argon atmosphere in a thick glass reaction tube fitted with a greaseless high-vacuum stopcock. In a typical experiment, the reactor was charged with a solution of the catalyst $(0.020 \mathrm{mmol})$ in THF (2 $\left.\mathrm{cm}^{3}\right), 2 \mathrm{mg}$ of molecular sieves in powder $(4 \AA)$ and the reactants in the following order: piperidine $(0.800 \mathrm{mmol}, 79 \mu \mathrm{L})$, tetradecane as internal standard $(0.350 \mathrm{mmol}, 91 \mu \mathrm{L})$ and styrene $(3.24 \mathrm{mmol}, 371$ $\mu \mathrm{L})$. The mixture was stirred at room temperature until the catalyst was completely dissolved, and then placed in a thermostatized oil bath at the required temperature.

The yield and selectivity were determined by GC HP $6890 \mathrm{~N}$ with an ionization detector fitted up to a HP Ultra- $1(25 \mathrm{~m} \times 0.32 \mathrm{~mm}$ d.i. $\times 0.17$ $\mu \mathrm{m})$ under the following conditions: Initial $\mathrm{T}^{\mathrm{a}} 50^{\circ} \mathrm{C}$ for $4 \mathrm{~min}$, ramp $15 \% \mathrm{~min}$, and final $\mathrm{T}^{\mathrm{a}} 250^{\circ}$ for $10 \mathrm{~min}$. Calibration was made with the internal standard tetradecane. Organic compounds were identified by Gas Chromatography-Mass Spectrometry (GC-MS) recorded in the mass range 1-1000 m/z on a Agilent 6890 GC-Agilent 5973 MS, equipped with a polar capillary column HP-5MS $(30 \mathrm{~m} \times 0.25 \mathrm{~mm}$ d.i. $\mathrm{x}$ $0.25 \mu \mathrm{m})$.

General Procedures for the Synthesis of Type I, $[R h(\operatorname{cod})(P \cap Z)]\left[B F_{4}\right]$, and Type II, $\left[R h(\operatorname{cod})(P \cap Z)_{2}\right][X]\left(X=B_{4}, P F_{6}\right.$, $\left.\mathrm{SbF}_{6}\right)$, Complexes.

Method A

$\left[\{\mathrm{Rh}(\mu-\mathrm{Cl})(\mathrm{cod})\}_{2}\right](246 \mathrm{mg}, 0.50 \mathrm{mmol})$ was added to a solution of the phosphine $\mathrm{P} \cap \mathrm{Z}(1.00 \mathrm{mmol}, 1$ equiv.) in acetone or tetrahydrofuran $(10 \mathrm{~mL})$ at $0^{\circ} \mathrm{C}$ and stirred for 1 hour. The volatiles were removed under reduced pressure and the residue disaggregated washing with cold pentane $(3 \times 4 \mathrm{~mL})$ at $0{ }^{\circ} \mathrm{C}$ to give red solids of the intermediate $[\mathrm{RhCl}(\mathrm{cod})(\mathrm{P} \cap \mathrm{Z})]$ complexes. The solids were dissolved in acetone or tetrahydrofuran $(10 \mathrm{~mL})$ at $0{ }^{\circ} \mathrm{C}$ and then the corresponding $\mathrm{AgX}(1.00$ $\mathrm{mmol}, \mathrm{X}=\mathrm{BF}_{4}, \mathrm{PF}_{6} ; \mathrm{SbF}_{6}$ ) was added. The $\mathrm{AgCl}$ formed was removed by filtration to giveorange solutions that were concentrated until $c a .0 .5$ $\mathrm{mL}$. The compounds were crystallized by slow diffusion of diethylether into the concentrated solutions. The crystals were separated by decantation and washed with diethyl ether.

\section{Method B}

A suspensión of $\left[\{\mathrm{Rh}(\mu-\mathrm{Cl})(\mathrm{cod})\}_{2}\right](246 \mathrm{mg}, 0.50 \mathrm{mmol})$ in acetone or tetrahydrofuran $(10 \mathrm{~mL})$ was treated with 2 equiv. of $\mathrm{AgX}(1.00 \mathrm{mmol})$. The suspension was stirred by $30 \mathrm{~min}$. and the $\mathrm{AgCl}$ formed was separated by filtration to give a yellow solution of the solvato species $\left[\mathrm{Rh}(\right.$ cod $\left.)(\text { solvent })_{2}\right]+$. The hemilabile phosphine $\mathrm{P} \cap \mathrm{Z}(1.00$ or 2.00 $\mathrm{mmol}$ ) was then added to the previously concentrated solution at $0{ }^{\circ} \mathrm{C}$ to give orange solutions. The solutions were concentrated under vacuum until ca. $0.5 \mathrm{~mL}$ and layered with diethylether to give crystals of the complexes that were separated by decantation, washed with diethyl ether, and vacuum dried.

\section{Method C}

The slow addition of a solution of the hemilabile phosphine $P \cap Z(1.00$ $\mathrm{mmol}$ or $2.00 \mathrm{mmol})$ in acetone $(2 \mathrm{~mL})$ to a suspensión of $\left[\mathrm{Rh}(\mathrm{cod})_{2}\right]\left[\mathrm{BF}_{4}\right](1.00 \mathrm{mmol})$ in acetone gave bright orange solutions. The compounds were obtained as crystals by slow diffusion of diethyl ether into the previously concentrated solutions. The crystals were separated by decantation, washed with diethyl ether, and vacuum dried.

\section{Method D}


Two equivalents of the corresponding fosfonium salt $[H(P \cap Z)]\left[B F_{4}\right]$ $(1.000 \mathrm{mmol})$ were added to a suspension of $\left[\{\mathrm{Rh}(\mu-\mathrm{OMe})(\mathrm{cod})\}_{2}\right]$ $(242.1 \mathrm{mg}, 0.500 \mathrm{mmol})$ in acetone $(10 \mathrm{~mL})$ to give yellow solutions that were stirred for $30 \mathrm{~min}$. at room temperature. The volatiles were removed under reduced pressure and the residue disaggregated washing with cold pentane $(3 \times 4 \mathrm{~mL})$ at $0{ }^{\circ} \mathrm{C}$ to give solids. The compounds were obtained as orange crystals by slow diffusion of diethyl ether into concentrated solutions in acetone. The crystals were separated by decantation, washed with diethyl ether, and vacuum dried.

Full experimental data on the synthesis and characterization of the new complexes is provided in the Supplementary Material. Spectroscopic characterization of $\mathbf{1}$ and $\mathbf{1 4}$, as representative examples for Type I and II complexes, respectively, is as follows:

[Rh(cod) $\left.\left(\mathrm{Ph}_{2} \mathrm{P}\left(\mathrm{CH}_{2}\right)_{2} \mathrm{OMe}\right)\right]\left[\mathrm{BF}_{4}\right]$ (1). [ $\left.[\mathrm{Rh}(\mu-\mathrm{Cl})(\mathrm{cod})\}_{2}\right](246 \mathrm{mg}, 0.50$ $\mathrm{mmol}$ ), $\mathrm{Ph}_{2} \mathrm{P}\left(\mathrm{CH}_{2}\right)_{2} \mathrm{OMe}$ (244 mg, $1.00 \mathrm{mmol}$ ); yield: 63\% (Method A), 65\% (Method B), 58\% (Method C), 60\% (Method D); elemental analysis of $\mathrm{C}_{23} \mathrm{H}_{29} \mathrm{BF}_{4} \mathrm{OPRh}$ calcd (\%): $\mathrm{C} 50.95, \mathrm{H} 5.39$; found: $\mathrm{C} 50.71$, $\mathrm{H} 4.87 ;{ }^{1} \mathrm{H}$ NMR $\left(298 \mathrm{~K}, \mathrm{CDCl}_{3}\right): \delta=7.66-7.27$ (m, 10H; Ph), 5.44 (br, $2 \mathrm{H}$; =CH cod), $3.79\left(\mathrm{dt}, 2 \mathrm{H} ; \mathrm{J}_{\mathrm{HP}}=21.2, \mathrm{~J}_{\mathrm{HH}}=5.9, \mathrm{CH}_{2} \mathrm{O}\right), 3.67(\mathrm{~s}, 3 \mathrm{H}$; $\left.\mathrm{OCH}_{3}\right), 3.41(\mathrm{br}, 2 \mathrm{H}$; $=\mathrm{CH} \operatorname{cod}), 2.87\left(\mathrm{dt}, 2 \mathrm{H}, \mathrm{J}_{\mathrm{HP}}=9.5, \mathrm{~J}_{\mathrm{HH}}=5.9\right.$, $\mathrm{CH}_{2} \mathrm{P}$ ), 2.52 (m br, 4H; $\mathrm{CH}_{2} \operatorname{cod}$ ), 2.06 (m br, 4H; $\mathrm{CH}_{2} \operatorname{cod}$ ); ${ }^{31} \mathrm{P}\left\{{ }^{1} \mathrm{H}\right\}$ NMR $\left(298 \mathrm{~K}, \mathrm{CDCl}_{3}\right): \delta=40.89\left(\mathrm{~d} ; \mathrm{J}_{\mathrm{PRh}}=151.5\right) ;{ }^{13} \mathrm{C}\left\{{ }^{1} \mathrm{H}\right\}$ NMR $(298 \mathrm{~K}$, $\left.\mathrm{CDCl}_{3}\right): \delta=132.91\left(\mathrm{~d} ; J_{\mathrm{CP}}=11.4, \mathrm{C}_{0}\right), 132.02\left(\mathrm{C}_{\mathrm{p}}\right), 129.64\left(\mathrm{~d} ; J_{\mathrm{CP}}=\right.$ 10.4, $\left.C_{m}\right), 127.47\left(d ; J_{C P}=46.0, C_{i}\right), 108.28\left(d d ; J_{C R h}=9.6, J_{C P}=7.0\right.$, $=\mathrm{CH} \operatorname{cod}), 75.13\left(\mathrm{CH}_{2}\right), 68.95\left(\mathrm{~d} ; J_{\mathrm{CRh}}=15.5,=\mathrm{CH} \operatorname{cod}\right), 64.49\left(\mathrm{OCH}_{3}\right)$, $32.41\left(\mathrm{CH}_{2} \mathrm{cod}\right), 28.45\left(\mathrm{~d} ; \mathrm{J}_{\mathrm{CP}}=24.4, \mathrm{CH}_{2} \mathrm{P}\right), 27.77\left(\mathrm{CH}_{2} \mathrm{cod}\right)$;

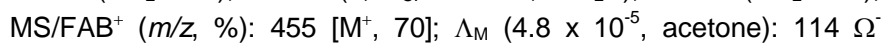
${ }^{1} \mathrm{~cm}^{2} \mathrm{~mol}^{-1}(1: 1)$.

[Rh(cod) $\left\{\square \boldsymbol{K}^{1}-\mathrm{P}-\mathrm{Ph}_{2} \mathrm{P}\left(\mathrm{CH}_{2}\right)_{2} \mathrm{OMe}_{2}\right]\left[\mathrm{BF}_{4}\right]$ (14). [ $\left.[\mathrm{Rh}(\mu-\mathrm{Cl})(\mathrm{cod})\}_{2}\right](144$ $\mathrm{mg}, 0.29 \mathrm{mmol}), \mathrm{Ph}_{2} \mathrm{P}\left(\mathrm{CH}_{2}\right)_{2} \mathrm{OMe}$ (286 mg, $\left.1.17 \mathrm{mmol}\right)$; yield: $42 \%$ (Method B); elemental analysis of $\mathrm{C}_{38} \mathrm{H}_{46} \mathrm{BF}_{4} \mathrm{O}_{2} \mathrm{P}_{2} \mathrm{Rh}$ calcd (\%): $\mathrm{C}$ 58.03, H 5.89; found: C 57.69, H 5.83; ${ }^{1} \mathrm{H}$ NMR (298K, $\left.\mathrm{CDCl}_{3}\right): \delta=$ $7.53-7.40(\mathrm{~m}, 10 \mathrm{H} ; \mathrm{Ph}), 4.36(\mathrm{br}, 4 \mathrm{H} ;=\mathrm{CH} \operatorname{cod}), 3.86\left(\mathrm{~m}, 4 \mathrm{H} ; \mathrm{CH}_{2}\right)$, 3.41 (s, $\left.6 \mathrm{H} ; \mathrm{OCH}_{3}\right), 2.56\left(\mathrm{br}, 4 \mathrm{H} ; \mathrm{CH}_{2}\right), 2.35-1.80\left(\mathrm{~m}, 8 \mathrm{H} ; \mathrm{CH}_{2} \mathrm{cod}\right)$; ${ }^{31} \mathrm{P}\left\{{ }^{1} \mathrm{H}\right\}$ NMR $\left(298 \mathrm{~K}, \mathrm{CDCl}_{3}\right): \delta=23.85\left(\mathrm{~d} ; \mathrm{J}_{\mathrm{PRh}}=143.8\right) ;{ }^{13} \mathrm{C}\left\{{ }^{1} \mathrm{H}\right\} \mathrm{NMR}$ (298K, $\mathrm{CDCl}_{3}$ ): $\delta=132.91$ (d; $J_{\mathrm{CP}}=12.5, \mathrm{C}_{\mathrm{o}}$ ), $130.85\left(\mathrm{C}_{\mathrm{p}}\right), 130.82$ (d; $\left.J_{\mathrm{CP}}=41.8, \mathrm{C}_{\mathrm{i}}\right), 128.72\left(\mathrm{~d} ; \mathrm{J}_{\mathrm{CP}}=10.0, \mathrm{C}_{\mathrm{m}}\right), 84.3\left(\mathrm{~d} \mathrm{br} ; \mathrm{J}_{\mathrm{CRh}}=12.5,=\mathrm{CH}\right.$ cod), $68.80\left(\mathrm{CH}_{2}\right), 58.81\left(\mathrm{OCH}_{3}\right), 30.30\left(\mathrm{CH}_{2} \mathrm{cod}\right), 28.62\left(\mathrm{~d} ; \mathrm{J}_{\mathrm{CP}}=25.8\right.$, $\left.\mathrm{CH}_{2} \mathrm{P}\right] ; \mathrm{MS} / \mathrm{FAB}^{+}(\mathrm{m} / \mathrm{z}, \%): 456(100)\left[\mathrm{M}^{+}-\mathrm{Ph}_{2} \mathrm{PCH}_{2} \mathrm{CH}_{2} \mathrm{OCH}_{3}\right] ; \Lambda_{\mathrm{M}}$ (4.8 $\times 10^{-5}$, acetone): $109 \Omega^{-1} \mathrm{~cm}^{2} \mathrm{~mol}^{-1}(1: 1)$.

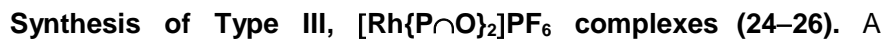
suspension of $\left[\mathrm{Rh}(\mu-\mathrm{Cl})(\mathrm{Coe})_{2}\right]_{2}(71.7 \mathrm{mg}, 0.100 \mathrm{mmol})$ in acetone (10 $\mathrm{cm}^{3}$ ) was treated with $\mathrm{AgPF}_{6}(50.6 \mathrm{mg}, 0.200 \mathrm{mmol})$ and allowed to react for $1 \mathrm{~h}$ at $0^{\circ} \mathrm{C}$. The $\mathrm{AgCl}$ formed was removed by filtration and the resulting yellow solution was poured into a solution of $\mathrm{Ar}_{2} \mathrm{P}\left(\mathrm{CH}_{2}\right)_{3} \mathrm{OEt}(0.40 \mathrm{mmol})$ in acetone $\left(1 \mathrm{~cm}^{3}\right)$ to give a red solution. The solvent was removed under vacuum and the residue was washed with diethyl ether $\left(3 \times 5 \mathrm{~cm}^{3}\right)$. The resulting orange solid was dissolved in THF $\left(1 \mathrm{~cm}^{3}\right)$ and layered with diethylether $\left(10 \mathrm{~cm}^{3}\right)$ at room temperature to render orange crystals of 4 which were filtered, washed with diethyl ether and dried in vacuo.

[Rh\{ $\left.\left.\mathrm{Ph}_{2} \mathrm{P}\left(\mathrm{CH}_{2}\right)_{3} \mathrm{OEt}\right\}_{2}\right] \mathrm{PF}_{6}$ (24). $\mathrm{Ph}_{2} \mathrm{P}\left(\mathrm{CH}_{2}\right)_{3} \mathrm{OEt}$ (108 mg, $0.40 \mathrm{mmol}$ ); yield: $72 \%$; elemental analysis of $\mathrm{C}_{34} \mathrm{H}_{42} \mathrm{~F}_{6} \mathrm{O}_{2} \mathrm{P}_{3} \mathrm{Rh}$ calcd (\%): C, 51.53; $\mathrm{H}, 5.34$; found: C, 51.62; $\mathrm{H}, 5.38 ;{ }^{1} \mathrm{H}$ NMR $\left(258 \mathrm{~K}\right.$, THF- $\left.d_{8}\right)$ : $\delta=7.53-$ $7.15(\mathrm{~m}, 2 \mathrm{H} ; 4 \times \mathrm{Ph}), 4.09$ (br, $\left.4 \mathrm{H} ; 2 \times \mathrm{CH}_{2} \mathrm{O}\right), 3.68\left(\mathrm{q}, 4 \mathrm{H} ; \mathrm{J}_{\mathrm{HH}}=6.8\right.$, $\left.2 \times \mathrm{CH}_{2} \mathrm{CH}_{3}\right), 2.49\left(\mathrm{br}, 4 \mathrm{H} ; 2 \times \mathrm{CH}_{2}\right), 1.80\left(\mathrm{~m}, 4 \mathrm{H} ; 2 \times \mathrm{CH}_{2}\right), 1.50(\mathrm{t}, 6 \mathrm{H}$; $\left.J_{\mathrm{HH}}=6.8,2 \times \mathrm{CH}_{2} \mathrm{CH}_{3}\right) ;{ }^{31} \mathrm{P}\left\{{ }^{1} \mathrm{H}\right\}$ NMR $\left(258 \mathrm{~K}, \mathrm{THF}-d_{8}\right): 46.45\left(\mathrm{~d} ; J_{\mathrm{PRh}}=\right.$ 204.8); ${ }^{13} \mathrm{C}\left\{{ }^{1} \mathrm{H}\right\}$ NMR (258K, THF- $\left.d_{8}\right): \delta=132.99\left(\mathrm{C}_{\mathrm{o}}\right), 129.54\left(\mathrm{C}_{\mathrm{p}}\right)$, $127.90\left(\mathrm{C}_{\mathrm{m}}\right), 73.56\left(\mathrm{CH}_{2} \mathrm{O}\right), 70.85\left(\mathrm{CH}_{2} \mathrm{CH}_{3}\right), 28.82$ (dd; J $\mathrm{J}_{\mathrm{CP}}=13.6$, $\left.\mathrm{CH}_{2} \mathrm{P}\right), 22.84\left(\mathrm{CH}_{2}\right), 14.72\left(\mathrm{CH}_{2} \mathrm{CH}_{3}\right) ; \mathrm{MS} / \mathrm{ESI}+(\mathrm{MeOH}, \mathrm{m} / \mathrm{z}): 647\left(\mathrm{M}^{+}\right)$.
$\left[\mathrm{Rh}\left\{\mathrm{\kappa}^{2}-\mathrm{P}, \mathrm{O}-\left(\mathbf{4}-\mathrm{MeC}_{6} \mathrm{H}_{4}\right)_{2} \mathrm{P}\left(\mathrm{CH}_{2}\right)_{3} \mathrm{OEt}\right\}_{2}\right]\left[\mathrm{PF}_{6}\right] \quad$ (25). (4- $\left.\mathrm{MeC}_{6} \mathrm{H}_{4}\right)_{2}$ $\mathrm{P}\left(\mathrm{CH}_{2}\right)_{3} \mathrm{OEt}(119,3 \mathrm{mg}, 0.40 \mathrm{mmol})$; yield: $64 \%$; elemental analysis of $\mathrm{C}_{38} \mathrm{H}_{50} \mathrm{~F}_{6} \mathrm{O}_{2} \mathrm{P}_{3} \mathrm{Rh}$ calcd (\%): C, 53.78; $\mathrm{H}, 5.94$; found: $\mathrm{C}, 53.69 ; \mathrm{H}, 6.15$; ${ }^{1} \mathrm{H}$ NMR $\left(258 \mathrm{~K}, \mathrm{THF}-\mathrm{d}_{8}\right): \delta=7.40-6.97(\mathrm{~m}, 16 \mathrm{H} ; \mathrm{Ph}), 3.98(\mathrm{br}, 4 \mathrm{H}$; $\mathrm{CH}_{2} \mathrm{O}$ ), $3.63\left(\mathrm{q}, 4 \mathrm{H} ; \mathrm{J}_{\mathrm{HH}}=6.8, \mathrm{CH}_{2} \mathrm{Et}\right), 2.38\left(\mathrm{br}, 4 \mathrm{H} ; \mathrm{CH}_{2}\right), 2.28(\mathrm{~s}$, $\left.12 \mathrm{H} ; \mathrm{CH}_{3} \mathrm{C}_{6} \mathrm{H}_{4}\right), 1.88\left(\mathrm{~m}, 4 \mathrm{H} ; \mathrm{CH}_{2}\right), 1.39\left(\mathrm{t}, 6 \mathrm{H} ; \mathrm{J}_{\mathrm{HH}}=6.8, \mathrm{CH}_{3} \mathrm{Et}\right)$; ${ }^{31} \mathrm{P}\left\{{ }^{1} \mathrm{H}\right\}$ NMR $\left(258 \mathrm{~K}, \mathrm{THF}-\mathrm{d}_{8}\right): \delta=43.04\left(\mathrm{~d}, \mathrm{~J}_{\mathrm{PRh}}=204.7\right) ;{ }^{13} \mathrm{C}\left\{{ }^{1} \mathrm{H}\right\}$ NMR $\left(258 \mathrm{~K}, \mathrm{THF}-d_{8}\right): \delta=137.69\left(\mathrm{C}_{4 i 0}\right), 130.91\left(\mathrm{C}_{\mathrm{o}}\right), 126.63\left(\mathrm{C}_{\mathrm{m}}\right), 71.87$ $\left(\mathrm{CH}_{2} \mathrm{O}\right), 68.80\left(\mathrm{CH}_{2} \mathrm{Et}\right), 27.02\left(\mathrm{ft} ; J_{\mathrm{CP}}=13.4, \mathrm{CH}_{2} \mathrm{P}\right), 20.86\left(\mathrm{CH}_{2}\right)$, $18.59\left(\mathrm{CH}_{3} \mathrm{C}_{6} \mathrm{H}_{4}\right), 12.94\left(\mathrm{CH}_{3} \mathrm{Et}\right) ; \mathrm{MS} / \mathrm{ESI}+(\mathrm{MeOH}, \mathrm{m} / \mathrm{z}): 703.3\left(\mathrm{M}^{+}\right)$.

$\left[\mathrm{Rh}\left\{\boldsymbol{\kappa}^{2}-\mathrm{P}, \mathrm{O}-\left(\mathbf{4}-\mathrm{MeOC}_{6} \mathrm{H}_{4}\right)_{2} \mathrm{P}\left(\mathrm{CH}_{2}\right)_{3} \mathrm{OEt}\right\}_{2}\right]\left[\mathrm{PF}_{6}\right] \quad$ (26). (4- $\left.\mathrm{MeOC}_{6} \mathrm{H}_{4}\right)_{2}$ $\mathrm{P}\left(\mathrm{CH}_{2}\right)_{3} \mathrm{OEt}(135.04 \mathrm{mg}, 0.40 \mathrm{mmol})$; yield: $49.2 \% \%$; elemental analysis of $\mathrm{C}_{38} \mathrm{H}_{50} \mathrm{~F}_{6} \mathrm{O}_{4} \mathrm{P}_{3} \mathrm{Rh}$ calcd (\%): $\mathrm{C}, 51.83 ; \mathrm{H}, 5.72$; found: $\mathrm{C}$, 51.58; $\mathrm{H}, 5.90 .{ }^{1} \mathrm{H}$ NMR $\left(258 \mathrm{~K}, \mathrm{THF}-d_{8}\right): \delta=7.48-6.77(\mathrm{~m}, 16 \mathrm{H} ; \mathrm{Ph})$, $4.08\left(\mathrm{br}, 4 \mathrm{H} ; \mathrm{CH}_{2} \mathrm{O}\right), 3.79\left(\mathrm{~s}, 12 \mathrm{H} ; \mathrm{CH}_{3} \mathrm{OC}_{6} \mathrm{H}_{4}\right), 3.58\left(\mathrm{q}, 4 \mathrm{H}, \mathrm{J}_{\mathrm{HH}}=6.7\right.$; $\left.\mathrm{CH}_{2} \mathrm{Et}\right), 2.43\left(\mathrm{br}, 4 \mathrm{H} ; \mathrm{CH}_{2}\right), 1.81\left(\mathrm{~m}, 4 \mathrm{H} ; \mathrm{CH}_{2}\right), 1.49\left(\mathrm{t}, 6 \mathrm{H} ; \mathrm{J}_{\mathrm{HH}}=6.8\right.$, $\left.\mathrm{CH}_{3} \mathrm{Et}\right) ;{ }^{31} \mathrm{P}\left\{{ }^{1} \mathrm{H}\right\}$ NMR (258K, THF- $\left.d_{8}\right): \delta=43.94$ (d, $J_{\mathrm{P}-\mathrm{Rh}}=205.4$ ); ${ }^{13} \mathrm{C}\left\{{ }^{1} \mathrm{H}\right\}$ NMR (258K, THF- $\left.d_{8}\right): \delta=160.85\left(\mathrm{C}_{4 i 0}\right), 134.22\left(\mathrm{C}_{0}\right), 113.24$ $\left(\mathrm{C}_{\mathrm{m}}\right), 73.64\left(\mathrm{CH}_{2} \mathrm{O}\right), 70.62\left(\mathrm{CH}_{2} \mathrm{Et}\right), 54.51\left(\mathrm{CH}_{3} \mathrm{OC}_{6} \mathrm{H}_{4}\right), 29.19\left(\mathrm{ft} ; \mathrm{J}_{\mathrm{CP}}=\right.$ 13.3, $\left.\mathrm{CH}_{2} \mathrm{P}\right), 22.80\left(\mathrm{CH}_{2}\right), 14.78\left(\mathrm{CH}_{3} \mathrm{Et}\right) ; \mathrm{MS} / \mathrm{ESI}+(\mathrm{MeOH}, \mathrm{m} / \mathrm{z})$; $767.3\left(\mathrm{M}^{+}\right)$.

Synthesis of $\left[\mathrm{Rh}(\mathrm{cod})\left\{\left[\mathrm{K}^{1}-\mathrm{P}-\mathrm{Ph}_{2} \mathrm{PCH}_{2} \mathrm{OCH}_{3}\right\}\left(\mathrm{NCCH}_{3}\right)\right]\left[\mathrm{BF}_{4}\right]\right.$ (27). To a solution of $\left[\mathrm{Rh}(\mathrm{Cod})\left(\mathrm{NCCH}_{3}\right)_{2}\right]\left[\mathrm{BF}_{4}\right](165.1 \mathrm{mg}, 0.430 \mathrm{mmol})$ in tetrahydrofuran $(10 \mathrm{~mL})$ at $0{ }^{\circ} \mathrm{C}, \mathrm{Ph}_{2} \mathrm{PCH}_{2} \mathrm{OCH}_{3}(95.7 \mathrm{mg}, 0.42 \mathrm{mmol})$ was added, and stirred for 1 hour. The volatiles were removed under reduced pressure and the residue disaggregated washing with cold pentane $(3 \times 4 \mathrm{~mL})$ at $0{ }^{\circ} \mathrm{C}$ to give a yellow solid. Yield: $67 \%$ (Method C); elemental analysis of $\mathrm{C}_{24} \mathrm{H}_{30} \mathrm{BF}_{4} \mathrm{NOPRh}$ cald (\%): $\mathrm{C}, 50.64 ; \mathrm{H}$, 5.31; N, 2.46; found: C, 50.58; H, 5.13; N, 2.37. MS/FAB $(\mathrm{m} / \mathrm{z}, \%)$ : $441\left(\left[\mathrm{M}-\mathrm{NCCH}_{3}\right]^{+}, 100\right) .{ }^{1} \mathrm{H}$ NMR $\left(298 \mathrm{~K}, \mathrm{CDCl}_{3}\right): \delta$ 7.71-7.49 (m, $10 \mathrm{H} ; \mathrm{Ph}), 5.51\left(\mathrm{br}, 2 \mathrm{H} ;=\mathrm{CH}\right.$ cod), $4.36\left(\mathrm{~s}, 2 \mathrm{H} ; \mathrm{CH}_{2}\right), 3.76(\mathrm{br}, 2 \mathrm{H} ;=\mathrm{CH}$ cod), $3.55\left(\mathrm{~s}, 3 \mathrm{H} ; \mathrm{OCH}_{3}\right), 2.46\left(\mathrm{~m}, 4 \mathrm{H} ; \mathrm{CH}_{2} \mathrm{cod}\right), 2.25\left(\mathrm{~s}, 3 \mathrm{H} ; \mathrm{NCCH}_{3}\right)$, $2.12\left(\mathrm{~m}, 4 \mathrm{H} ; \mathrm{CH}_{2} \mathrm{cod}\right) .{ }^{31} \mathrm{P}\left\{{ }^{1} \mathrm{H}\right\} \mathrm{NMR}\left(298 \mathrm{~K}, \mathrm{CDCl}_{3}\right): \delta 20.01\left(\mathrm{~d}, \mathrm{~J}_{\mathrm{PRh}}=\right.$ 145.4). ${ }^{13} \mathrm{C}\left\{{ }^{1} \mathrm{H}\right\}$ NMR $\left(298 \mathrm{~K}, \mathrm{CDCl}_{3}\right): \delta 133.50\left(\mathrm{~d}, J_{\mathrm{CP}}=10.8 ; \mathrm{C}_{0}\right)$, $131.40\left(\mathrm{~d} ; J_{\mathrm{CP}}=2.2, C_{\mathrm{p}}\right), 129.02\left(\mathrm{~d}, J_{\mathrm{CP}}=10.0 ; C_{\mathrm{m}}\right), 128.38\left(\mathrm{C}_{\mathrm{i}}\right)$, $126.00\left(\mathrm{NCCH}_{3}\right), 105.24(\mathrm{br} ;=\mathrm{CH} \operatorname{cod}), 70.21\left(\mathrm{~d}, \mathrm{~J}_{\mathrm{CP}}=35.8 ; \mathrm{CH}_{2} \mathrm{P}\right)$, $61.76\left(\mathrm{~d} ; J_{\mathrm{CRh}}=10.0 ;=\mathrm{CH} \operatorname{cod}\right), 61.85\left(\mathrm{OCH}_{3}\right), 32.28,28.84\left(\mathrm{CH}_{2} \mathrm{COd}\right)$, $2.97\left(\mathrm{NCCH}_{3}\right)$.

CCDC 867297 - 867302 contains the supplementary crystallographic data for this paper. These data can be obtained free of charge from The Cambridge Crystallographic Data Centre via www.ccdc.cam.ac.uk/data_request/cif.

\section{Acknowledgements}

Financial support from Ministerio de Ciencia e Innovación (MICINN/FEDER) is gratefully acknowledged. Projects: CTQ201015221, and CONSOLIDER INGENIO-2010, MULTICAT (CSD200900050) and Factoría de Cristalización (CSD2006-0015). MIB thanks the Spanish MICINN and IUCH (Instituto Universitario de Catálisis Homogénea) for a predoctoral fellowship.

Keywords: hemilabile ligands $\bullet P, O$ ligands $\bullet$ intermolecular hydroamination $\bullet$ homogeneous catalysis $\bullet$ rhodium 
[1] a) J. Seayad, A. Tillack, M. Beller, Angew. Chem. Int. Ed. 2004, 43, 3368-3398; b) T. E. Müller, In Encyclopedia of Catalysis, Vol 3 (Ed. I. Horváth), John Wiley, 2002, pp. 492-518; c) J. J. Brunet, D. Neibecker, In Catalytic Heterofunctionalization (Eds. A. Togni, H. Grützmacher), WileyVCH, Weinheim, 2001, pp. 91-137; d) B. M. Trost, T. R. Veeroeven, In Comprehensive Organometllic Chemistry, Vol. 8 (Eds.: G. Wilkinson, F. G. A. Stone, E. W. Abel), Pergamon Press, Oxford, 1982, pp. 892-895.

[2] J. Seayad, A. Tillack, C. G. Hartung, M. Beller, Adv. Synth. Catal. 2002, 344, 795-813.

[3] a) R. Taube, In Applied Homogeneous Catalisis, 2nd ed., Vol. 1 (Eds. B. Cornils, W. A. Hermann), Wiley-VCH, Weinheim, Germany, 2002, pp. 513-524; b) A. M. Johns, N. Sakai, A. Ridder, J. F. Hartwig, J. Am. Chem. Soc. 2006, 128, 9306-9307.

[4] Significant literature references. Early Transition Metals: a) M. C. Wood, D. C. Leitch, C. S. Yeung, J. A. Kozak, L. L. Schafer, Angew. Chem., Int. Ed. 2007, 46, 354-358; b) C. Müller, C. Loos, N. Schulenberg, S. Doye, Eur. J. Org. Chem. 2006, 2499-2503; c) H. Kim, P. H. Lee, T. Livinghouse, Chem. Commun. 2005, 5205-5207. Late Transition Metals: d) T. O. Nguyen, B. Y. -W. Man, R. Hodgson Aus. J. Chem. 2011, 64, 741-746; e) Z. Liu, H. Yamamichi, S. T. Madrahimov, J. F. Hartwig J. Am. Chem. Soc. 2011, 133, 2772-2782; f) L. D. Julian, J. F. Hartwig, J. Am. Chem. Soc. 2010, 132, 13813-13822; g) K. D. Hesp, M. Stradiotto, ChemCatChem 2010, 2, 1192-1207; h) C. F. Bender, R. A. Widenhoefer, Org. Lett. 2006, 8, 5303-5305. Group f Elements: i) S. Hong, T. J. Marks Acc. Chem. Res. 2004, 37, 673-686; j) G. A. Molander, J. A. C. Romero, Chem. Rev. 2002, 102, 2161-2185.

[5] a) J.-S. Ryu, G. Y. Li, T. J. Marks, J. Am. Chem. Soc. 2003, 125, 1258412605; b) T. E. Müller, K. C. Hultzsch, M. Yus, F. Foubelo, M. Tada, Chem. Rev., 2008, 108, 3795-3892.

[6] D. R. Coulson, Tetrahedron Lett. 1971, 12, 429-430.

[7] D. Selent, D. Scharfenberg-Pfeiffer, G. Reck, R. Taube, J. Organomet. Chem. 1991, 415, 417-423.

[8] R. Taube, In Applied Homogeneous Catalysis, 2nd ed., Vol. 1 (Eds. B. Cornils, W. A. Hermann), Wiley-VCH, Weinheim, 2002, pp. 513-524.

[9] A. L. Casalnuovo, J. C. Calabrese, D. Milstein, J. Am. Chem. Soc. 1988, 110, 6738-6744.

[10] a) J. J. Brunet, G. Commenges, D. Neibecker, K, Philippot, L. Rosenberg, J. Organomet. Chem. 1996, 522, 117-122; b) ibid., Inorg. Chem, 1994, 33, 6373-6379; c) ibid., J. Organomet. Chem. 1994, 469, 221-228; d) J. J. Brunet, D. Neibecker, K. Philippot, Tetrahedron Lett., 1993, 34, 38773880 .

[11] a) M. Utsunomiya, J. F. Hartwig, J. Am. Chem. Soc. 2003, 125, 1428614287; b) M. Kawatsura, J. F. Hartwig, J. Am. Chem. Soc. 2000, 122, 9546-9547.

[12] a) J. L. Mcbee, A. T. Bell, T. D. Tilley, J. Am. Chem. Soc. 2008, 130, 16562-16571; b) D. Karshtedt, A. T. Bell, T. D. Tilley, J. Am. Chem. Soc. 2005, 127, 12640-12646;

[13] a) J. J. Brunet, N. C. Chu, M. Rodríguez-Zubiri, Eur. J. Inorg. Chem. 2007, 4711-4722; b) J. J. Brunet, N. C. Chu, O. Diallo, Organometallics 2005, 24, 3104-3110.

[14] C. Munro-Leighton, S. A. Delp, E. D. Blue, T. B. Gunnoe, Organometallics 2007, 26, 1483-1493.

[15] a) M. Utsunomiya, J. F. Hartwig, J. Am. Chem. Soc. 2005, 127, 57565757 ; b) J. Takaya, J. F. Hartwig, J. Am. Chem. Soc. 2004, 126, 27022703.

[16] M. Beller, M. Eichberger, H. Trauthwein, Angew. Chem., Int. Ed. Engl. 1997, 36, 2225-2227.

[17] M. Beller, H. Trauthwein, M. Eichberger, C. Breindl, J. Herwig, T. E. Müller, O. R. Thiel, Chem. Eur. J. 1999, 5, 1306-1319.

[18] M. Beller, H. Trauthwein, M. Eichberger, C. Breindl, T. E. Müller, Eur. J. Inorg. Chem. 1999, 7, 1121-1132.
[19] M. Utsunomiya, R. Kuwano, M. Kawatsura, J. F. Hartwig, J. Am. Chem Soc. 2003, 125, 5608-5609.

[20] a) N. D. Schley, G. E. Dobereiner, R. H. Crabtree, Organometallics 2011, 30, 4174-4179; b) D. B. Grotjahn, Chem. Lett. 2010, 39, 908-914; c) D. B Grotjahn, Dalton Trans. 2008, 6497-6508; d) Z. E. Clarke, P. T. Maragh, T. P. Dasgupta, D. G. Gusev, A. J. Lough, K. Abdur-Rashid, Organometallics 2006, 25, 4113-4117.

[21] M. V. Jiménez, J. J. Pérez-Torrente, M. I. Bartolomé, V. Gierz, F. J. Lahoz, L. A. Oro, Organometallics 2008, 27, 224-234.

[22] M. V. Jiménez, J. Fernández-Tornos, J. J. Pérez-Torrente, F. J. Modrego, S. Winterle, C. Cunchillos, F. J. Lahoz, L. A. Oro, Organometallics 2011 $30,5493-5508$.

[23] M. V. Jiménez, J. J. Pérez-Torrente, M. I. Bartolomé, E. Vispe, F. J. Lahoz, L. A. Oro, Macromolecules 2009, 42, 8146-8156.

[24] M. V. Jiménez, J. J. Pérez-Torrente, M. I. Bartolomé, F. J. Lahoz, L. A. Oro, Chem. Commun. 2010, 46, 5322-5324.

[25] M. V. Jiménez, J. J. Pérez-Torrente, M. I. Bartolomé, L. A. Oro, Synthesis 2009, 1916-1922.

[26] R. R. Schrock, J. A. Osborn, J. Am. Chem. Soc. 1971, 93, 3089-3091.

[27] a) S. Burling, L. D. Field, B. A. Messerle, K. Q. Vuong, P. Turner, Dalton Trans. 2003, 4181-4191; b) S. Gladiali, S. Medici, T. Kégl, L. Kollàr, Monatshefte für Chemie 2000, 131, 1351-1361.

[28] R. Bonnaire, D. Davoust, N. Platzer, Org. Magn. Reson. 1984, 22, 80-85.

[29] a) D. Cremer, J. A. Pople, J. Am. Chem. Soc. 1975, 97, 1354-1358; b) C. Giacovazzo, H. L. Monaco, D. Viterbo, F. Scordari, G. Gilli, G. Zanotti, M. Catti, In Fundamentals of Crystallography (Ed. C. Giacovazzo), OUP/International Union of Crystallography, Oxford University Press, USA, 1992, pp. 492-499.

[30] C. Janiak, J. Chem. Soc., Dalton Trans. 2000, 3885-3896.

[31] R. H. Crabree, M. W. Davis, M. F. Mellea, J. M. Mihelcis, Inorg. Chim. Acta 1983, 72, 223-226.

[32] a) P. Braunstein, F. Naud, A. Dedieu, M. -M. Rohmer, A. DeCian, S. J. Rettig, Organometallics, 2001, 20, 2966-2981; b) P. Bhattacharyya, A. M. Z. Slawin, M. B. Smith, J. D. Woollins, Inorg. Chem. 1996, 35, 3675-3682.

[33] Cremer and Popple parameters for 24: $P 1 Q_{T}=0.670(3) \AA, \Phi \square 178(4), \theta$ $=175.1(3)^{\circ}$ and $P 2 Q_{T}=0.636(3) \AA, \Phi \square-60(4), \theta=175.4(4)^{\circ} ; 25: P 1 Q_{T}$ $=0.650(3) \AA, \Phi \square=65(3), \theta=5.0(3)^{\circ}$ and $P 2 Q_{T}=0.665(3) \AA \Phi \square=61(4)$, $\theta=3.5(3)$.

[34] a) X. Shen, S. L. Buchwald, Angew. Chem. Int. Ed. 2010, 49, 564-567; b) C. F. Bender, W. B. Hudson, R. A. Widenhoefer, Organometallics 2008, 27, 2356-2358; c) X. Han, R. A. Widenhoefer, Angew. Chem. Int. Ed. 2006, 45, 1747-1749

[35] M. Beller, H. Trauthwein, M. Eichberger, C. Breindl, J. Herwig, T. E. Müller, O. R. Thiel, Chem. Eur. J. 1999, 5, 1306-1319.

[36] a) M. Rodríguez-Zubiri, S. Anguille, J. J. Brunet, J. Mol. Catal. A-Chem. 2007, 271, 145-150; b) J. E. Kang, H. B. Kim, J. W. Lee, S. Shin, Org. Lett. 2006, 8, 3537-3540; c) D. Nama, P. S. Pregosin, A. Albinati, S. Rizzato, Organometallics 2007, 26, 2111-2121; d) S. Burling, L. D. Field, H. L. Li, B. A. Messerle, P. Turner, Eur. J. Inorg. Chem. 2003, 3179-3184. [37] G. Giordano, R. H. Crabtree, Inorg. Synth. 1979, 19, 218-219.

[38] M. Green, T. A. Kuc, S. H. Taylor, J. Chem. Soc. A, 1971, 2334-2337.

[39] A. van der Ent, A. L. Onderdelinden, Inorg. Synth. 1973, 14, 92-94.

Received: ((will be filled in by the editorial staff))

Published online: ((will be filled in by the editorial staff)) 


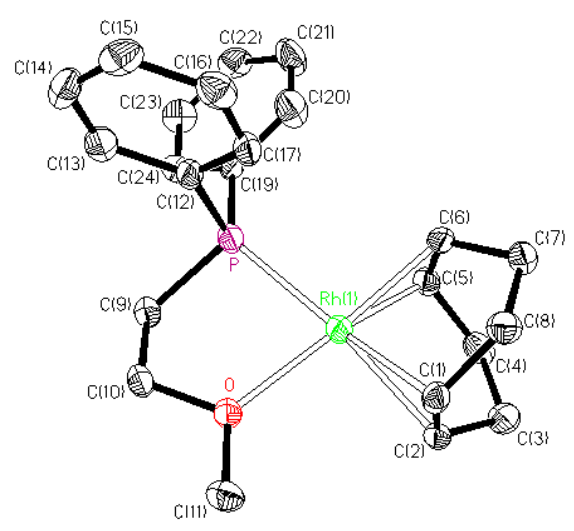

1

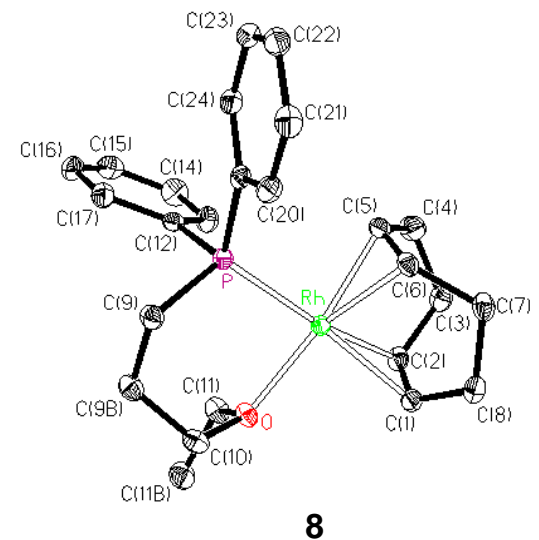

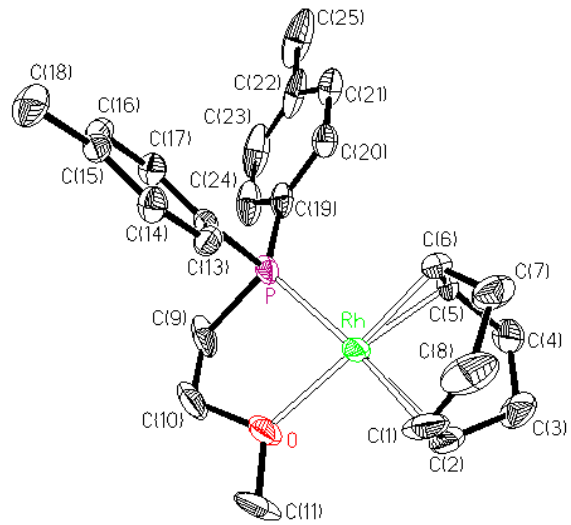

2

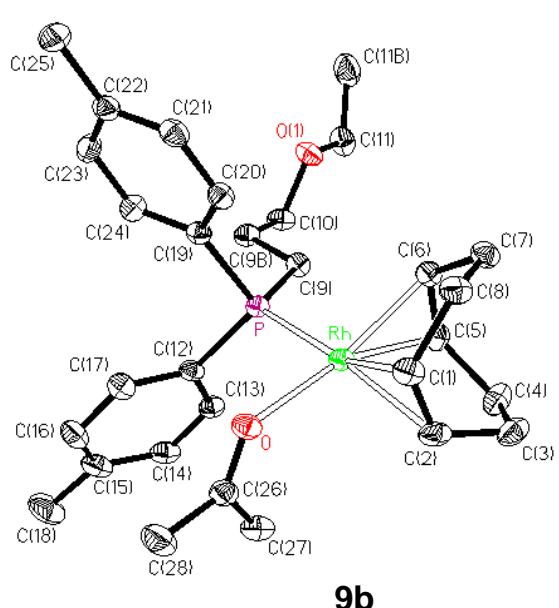

Figure 2. Molecular structures of the cationic complexes of $\mathbf{1}, \mathbf{2}, \mathbf{8}$, and $\mathbf{9 b}$. Hydrogen atoms have been omitted for clarity. 


\begin{tabular}{|c|c|c|c|c|c|c|}
\hline \multirow[b]{2}{*}{ Entry } & \multirow[b]{2}{*}{$P \cap Z$ Ligand } & \multirow[b]{2}{*}{ Catalyst } & \multicolumn{2}{|c|}{$8 \mathrm{~h}$} & \multicolumn{2}{|c|}{$20 \mathrm{~h}$} \\
\hline & & & Conv. $^{c}$ & Selec. ${ }^{d}$ & Conv. ${ }^{c}$ & Selec. ${ }^{d}$ \\
\hline 1 & $\mathrm{Ph}_{2} \mathrm{P}\left(\mathrm{CH}_{2}\right)_{2} \mathrm{OMe}$ & 1 & 28 & 100:0 & 53 & $98: 2$ \\
\hline 2 & $\mathrm{Ph}_{2} \mathrm{P}\left(\mathrm{CH}_{2}\right)_{2} \mathrm{NMe}_{2}$ & 11 & & & 14 & 100:0 \\
\hline 3 & $\mathrm{Ph}_{2} \mathrm{P}\left(\mathrm{CH}_{2}\right)_{2} \mathrm{SMe}$ & 13 & & & 3 & 100:0 \\
\hline 4 & $\mathrm{Ph}_{2} \mathrm{P}\left(\mathrm{CH}_{2}\right) \mathrm{OMe}$ & 27 & & & 5 & 100:0 \\
\hline 5 & $\mathrm{Ph}_{2} \mathrm{P}\left(\mathrm{CH}_{2}\right)_{3} \mathrm{OMe}$ & 4 & 35 & $97: 3$ & 60 & $98: 2$ \\
\hline 6 & $\mathrm{Ph}_{2} \mathrm{P}\left(\mathrm{CH}_{2}\right)_{2} \mathrm{OEt}$ & 5 & 47 & $100: 0$ & 65 & $98: 2$ \\
\hline 7 & $\mathrm{Ph}_{2} \mathrm{P}\left(\mathrm{CH}_{2}\right)_{3} \mathrm{OEt}$ & 8 & 61 & $98: 2$ & 75 & $97: 3$ \\
\hline 8 & $\mathrm{Ph}_{2} \mathrm{P}\left(\mathrm{CH}_{2}\right)_{3} \mathrm{OBu}$ & 28 & & & 43 & $98: 2$ \\
\hline 9 & $\left(4-\mathrm{CH}_{3} \mathrm{C}_{6} \mathrm{H}_{4}\right)_{2} \mathrm{P}\left(\mathrm{CH}_{2}\right)_{3} \mathrm{OEt}$ & 9 & 66 & $97: 3$ & 88 & $96: 4$ \\
\hline 10 & $\left(4-\mathrm{CF}_{3} \mathrm{C}_{6} \mathrm{H}_{4}\right)_{2} \mathrm{P}\left(\mathrm{CH}_{2}\right)_{3} \mathrm{OEt}$ & 10 & & & 6 & 100:0 \\
\hline 11 & $\left(4-\mathrm{CH}_{3} \mathrm{C}_{6} \mathrm{H}_{4}\right)_{2} \mathrm{P}\left(\mathrm{CH}_{2}\right)_{2} \mathrm{OMe}$ & 2 & 33 & $97: 3$ & 59 & $98: 2$ \\
\hline 12 & $\left(4-\mathrm{CF}_{3} \mathrm{C}_{6} \mathrm{H}_{4}\right)_{2} \mathrm{P}\left(\mathrm{CH}_{2}\right)_{2} \mathrm{OEt}$ & 7 & & & 4 & 100:0 \\
\hline 13 & $\left(2-\mathrm{CH}_{3} \mathrm{C}_{6} \mathrm{H}_{4}\right)_{2} \mathrm{P}\left(\mathrm{CH}_{2}\right)_{2} \mathrm{OMe}$ & 3 & & & 8 & 100:0 \\
\hline \multicolumn{7}{|c|}{$\begin{array}{l}{ }^{\text {a }} \text { Styrene/piperidine/cat. } 160 / 40 / 1 ;[\mathrm{Rh}]=0.01 \mathrm{M} \text { in THF, } 80{ }^{\circ} \mathrm{C} .{ }^{\mathrm{b}} \text { Standard conditions of } \\
\text { analysis. Reaction products: }(E)-1 \text {-styrylpiperidine, } 1 \text {-phenylethylpiperidine, ethylbenzene. } \\
\text { Conversion relative to piperidine (\%). Determined by GC analysis using tetradecane as an } \\
\text { internal standard. }{ }^{\mathrm{c}} \text { Selectivity: enamine/amine ratio. }\end{array}$} \\
\hline
\end{tabular}

\begin{tabular}{|c|c|c|c|c|c|c|c|c|c|}
\hline \multirow[b]{2}{*}{ Entry } & \multirow[b]{2}{*}{$\mathrm{P} \cap \mathrm{O}$ Ligand } & \multirow[b]{2}{*}{ Catalyst } & \multirow[b]{2}{*}{$\mathrm{m}^{\mathrm{a}}$} & \multicolumn{2}{|c|}{$4 \mathrm{~h}$} & \multicolumn{2}{|c|}{$8 \mathrm{~h}$} & \multicolumn{2}{|c|}{$20 \mathrm{~h}$} \\
\hline & & & & Conv. $^{\mathrm{c}}$ & Selec. $^{d}$ & Conv. $^{c}$ & Selec. ${ }^{d}$ & Conv. $^{c}$ & Selec. ${ }^{d}$ \\
\hline 1 & $\mathrm{Ph}_{2} \mathrm{P}\left(\mathrm{CH}_{2}\right)_{2} \mathrm{OMe}$ & 1 & 1 & & & 28 & $100: 0$ & 53 & $98: 2$ \\
\hline 2 & $\mathrm{Ph}_{2} \mathrm{P}\left(\mathrm{CH}_{2}\right)_{2} \mathrm{OMe}$ & 14 & 2 & & & 42 & $98: 2$ & 73 & $97: 3$ \\
\hline 3 & $\mathrm{Ph}_{2} \mathrm{P}\left(\mathrm{CH}_{2}\right)_{3} \mathrm{OMe}$ & 4 & 1 & & & 35 & $97: 3$ & 60 & $98: 2$ \\
\hline 4 & $\mathrm{Ph}_{2} \mathrm{P}\left(\mathrm{CH}_{2}\right)_{3} \mathrm{OMe}$ & 15 & 2 & & & 50 & $98: 2$ & 78 & $97: 3$ \\
\hline 5 & $\left(4-\mathrm{CH}_{3} \mathrm{C}_{6} \mathrm{H}_{4}\right)_{2} \mathrm{P}\left(\mathrm{CH}_{2}\right)_{3} \mathrm{OMe}$ & 16 & 2 & & & 73 & $97: 3$ & 92 & $98: 2$ \\
\hline 6 & $\mathrm{Ph}_{2} \mathrm{P}\left(\mathrm{CH}_{2}\right)_{2} \mathrm{OEt}$ & 5 & 1 & & & 47 & $100: 0$ & 65 & $98: 2$ \\
\hline 7 & $\mathrm{Ph}_{2} \mathrm{P}\left(\mathrm{CH}_{2}\right)_{2} \mathrm{OEt}$ & 17 & 2 & & & 54 & 100:0 & 77 & $96: 4$ \\
\hline 8 & $\left(4-\mathrm{CH}_{3} \mathrm{C}_{6} \mathrm{H}_{4}\right)_{2} \mathrm{P}\left(\mathrm{CH}_{2}\right)_{2} \mathrm{OEt}$ & 18 & 2 & & & 75 & $97: 3$ & 87 & $98: 2$ \\
\hline 9 & $\mathrm{Ph}_{2} \mathrm{P}\left(\mathrm{CH}_{2}\right)_{3} \mathrm{OEt}$ & 8 & 1 & & & 61 & $98: 2$ & 82 & $97: 3$ \\
\hline 10 & $\mathrm{Ph}_{2} \mathrm{P}\left(\mathrm{CH}_{2}\right)_{3} \mathrm{OEt}$ & $19 a$ & 2 & 82 & $96: 4$ & 96 & $97: 3$ & & \\
\hline 11 & $\mathrm{Ph}_{2} \mathrm{P}\left(\mathrm{CH}_{2}\right)_{3} \mathrm{OEt}$ & $19 b$ & 2 & 92 & $96: 4$ & 97 & $96: 4$ & & \\
\hline 12 & $\mathrm{Ph}_{2} \mathrm{P}\left(\mathrm{CH}_{2}\right)_{3} \mathrm{OEt}$ & $19 \mathrm{c}$ & 2 & 70 & $94: 6$ & 90 & $95: 5$ & & \\
\hline 11 & $\left(4-\mathrm{CH}_{3} \mathrm{C}_{6} \mathrm{H}_{4}\right)_{2} \mathrm{P}\left(\mathrm{CH}_{2}\right)_{3} \mathrm{OEt}$ & 9 & 1 & & & 66 & $97: 3$ & 88 & $96: 4$ \\
\hline 12 & $\left(4-\mathrm{CH}_{3} \mathrm{C}_{6} \mathrm{H}_{4}\right)_{2} \mathrm{P}\left(\mathrm{CH}_{2}\right)_{3} \mathrm{OEt}$ & 20 & 2 & 86 & $96: 4$ & 98 & $97: 3$ & 100 & $98: 2$ \\
\hline 13 & $\left(4-\mathrm{CH}_{3} \mathrm{OC}_{6} \mathrm{H}_{4}\right)_{2} \mathrm{P}\left(\mathrm{CH}_{2}\right)_{3} \mathrm{OEt}$ & 21 & 2 & 49 & $98: 2$ & 73 & $97: 3$ & 84 & $98: 2$ \\
\hline 14 & $\mathrm{Ph}_{2} \mathrm{P}\left(\mathrm{CH}_{2}\right)_{3} \mathrm{OBu}$ & 28 & 1 & & & & & 44 & $98: 2$ \\
\hline 15 & $\mathrm{Ph}_{2} \mathrm{P}\left(\mathrm{CH}_{2}\right)_{3} \mathrm{OBu}$ & 22 & 2 & & & 82 & $96: 4$ & 95 & $97: 3$ \\
\hline $\begin{array}{l}{ }^{\text {a }} \text { Num } \\
\text { relativ } \\
\text { enam }\end{array}$ & $\begin{array}{l}\text { of hemilabile phosphines } \\
\text { piperidine (\%). Determir } \\
\text { amine ratio. }\end{array}$ & $\begin{array}{l}\text {. }{ }^{b} \text { Styrene } \\
\text { ined by G }\end{array}$ & pen & e/cat. & $\begin{array}{l}\text { 40/1; } \\
\text { adec }\end{array}$ & $\begin{array}{l}0.0 \\
\text { s an }\end{array}$ & $\begin{array}{l}\text { in } \mathrm{THF} \\
\text { ernal s }\end{array}$ & $\begin{array}{l}{ }^{\circ} \mathrm{C} .{ }^{c} \mathrm{C} \\
\text { ard. }\end{array}$ & $\begin{array}{l}\text { nversion } \\
\text { lectivity: }\end{array}$ \\
\hline
\end{tabular}




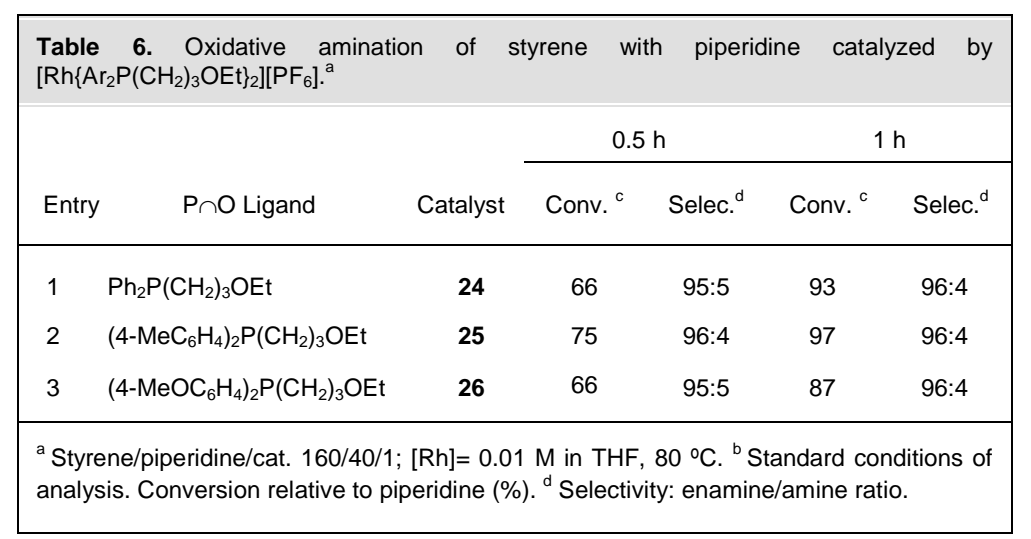

Entry for the Table of Contents (Please choose one layout only)

Layout 1:

FULL PAPER

Hemilabile ligands: The design of rhodium (I) catalysts based on P,Ofunctionalized ligands with a 3-ethoxy-propyl hemilabile moiety has allowed reaching unprecedented turn-over frequencies, up to $80 \mathrm{~h}^{-1}$, in the catalytic antiMarkovnikov oxidative amination of styrene with piperidine with excellent selectivity to the enamine (F)-1-stvrvlnineridine

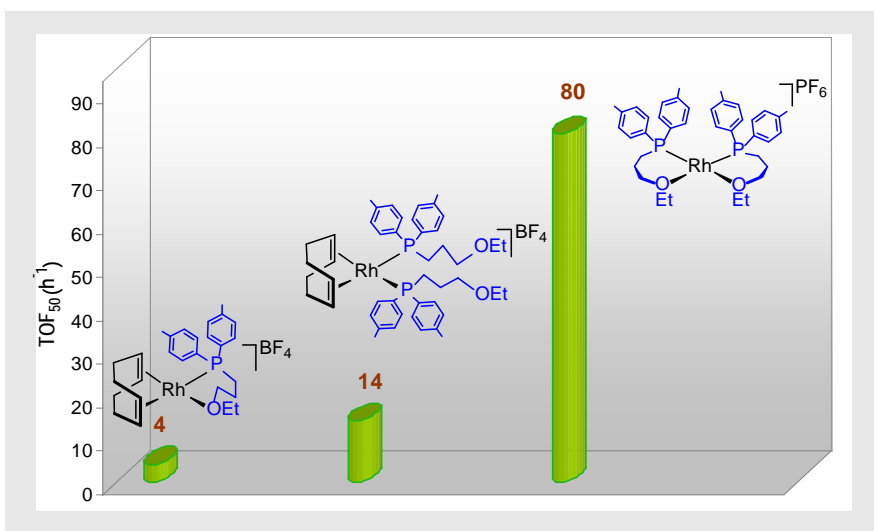

M. Victoria Jiménez, ${ }^{\star} M$ Isabel Bartolomé, Jesús J. Pérez-Torrente, * Fernando J. Lahoz, and Luis A. Oro

Page No. - Page No.

Rhodium(I) Complexes with Hemilabile

Phosphines: Rational

Design for Efficient

Oxidative Amination Catalysts. 